
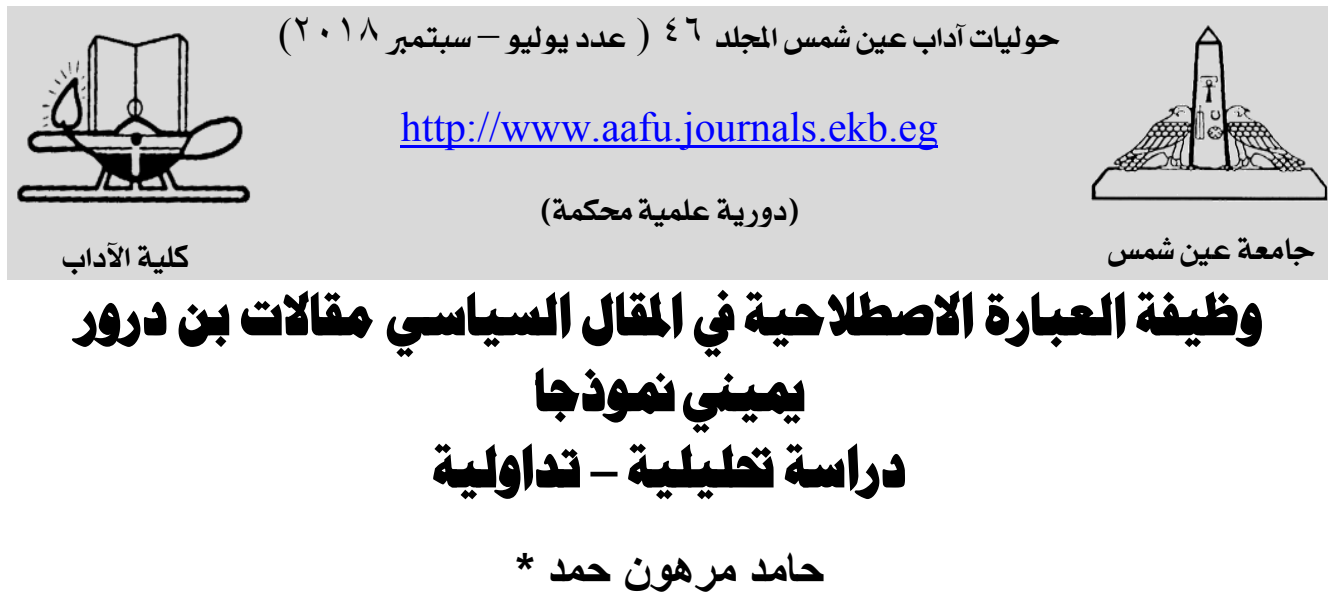

Baghdad University - College of Languages - Department of Hebrew Language

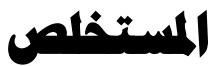

يسعى هذا البحث إلى تسليط الضوء على أحد الأساليب اللغوية البلاغية المهمة ألا

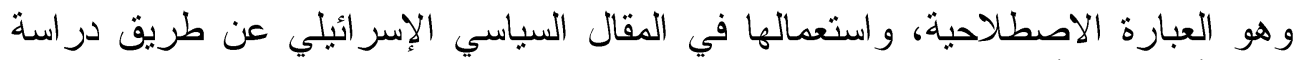

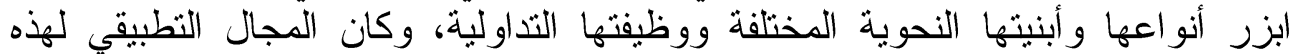

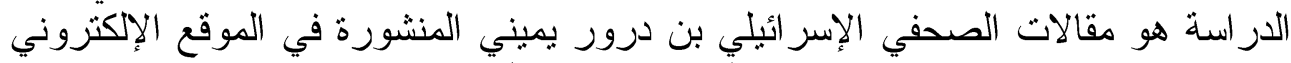

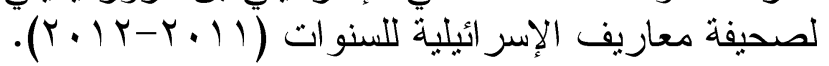
قسم البحث إلى قسمين، نظري وتطبيقي، الجانب النظري تضمن مدخلا تعريفياً

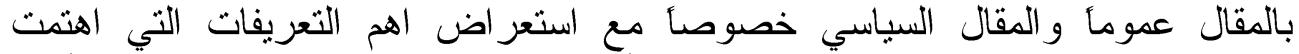

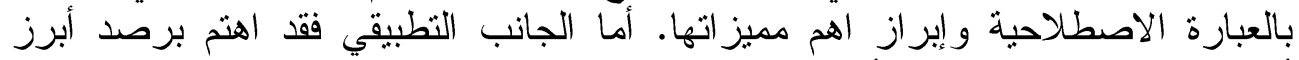

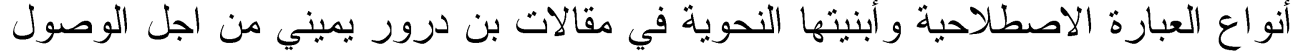

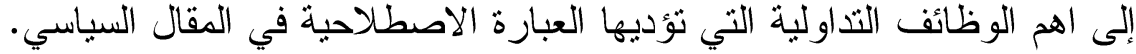

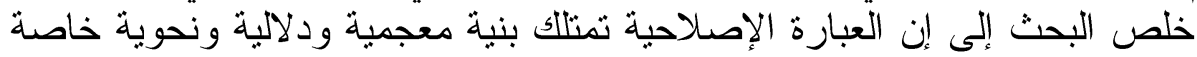

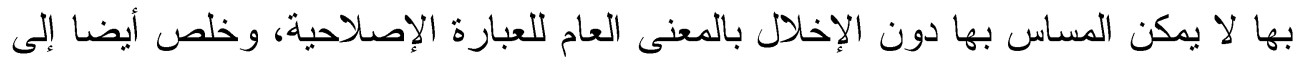
إن الهم الأبنية النحوية للعبارة الاصطلاحية في مقالات يميني هي: الإنية (العبارة الاسمية،

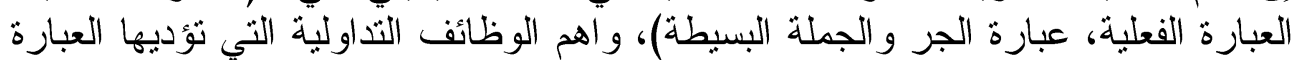
هي: إقناع المثلقي، ثبيان القصد ووظائف لغوية و أسلوبية مختلفة. 


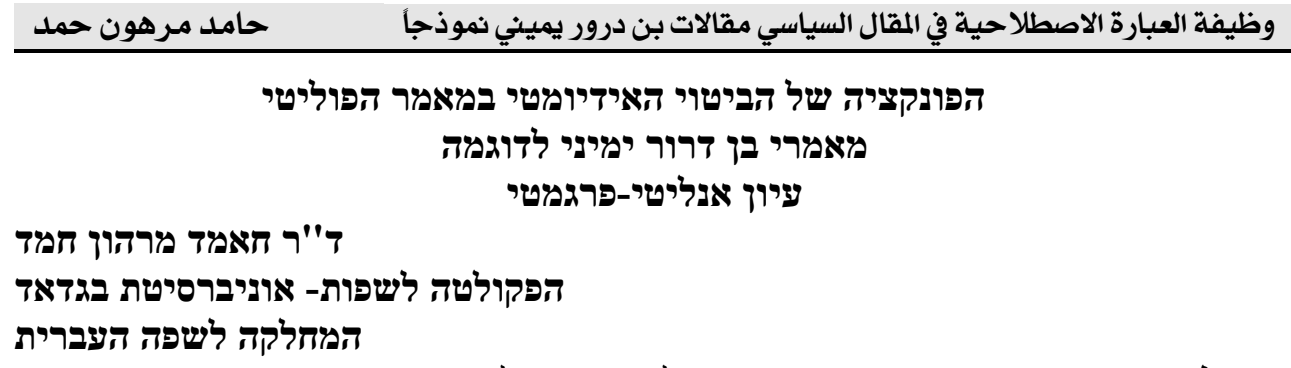

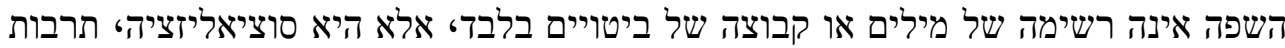

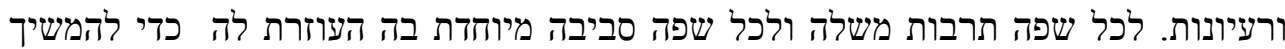

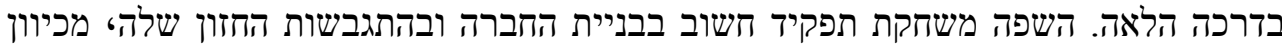
שהיא הקשר בין כל בני החברהת.

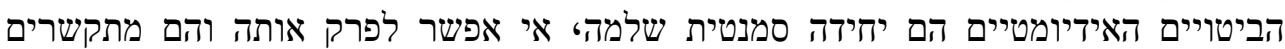

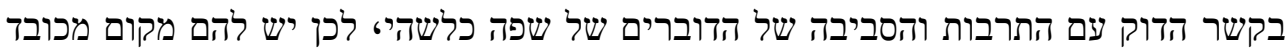

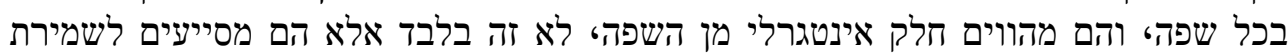

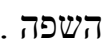

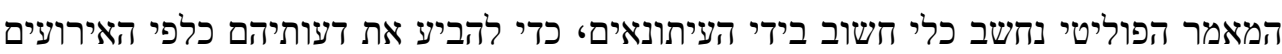

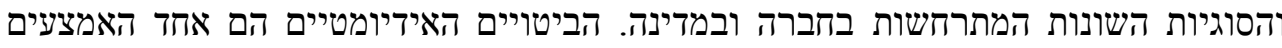

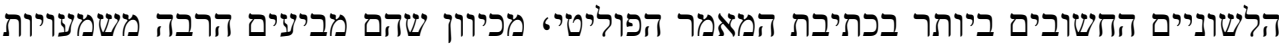

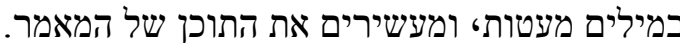

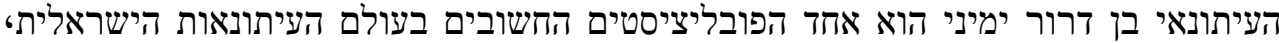

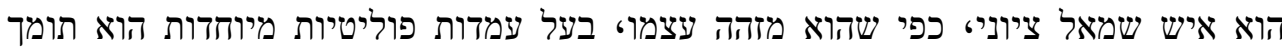

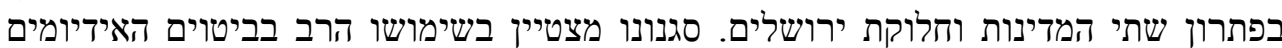

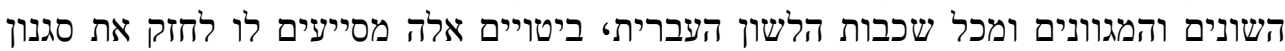

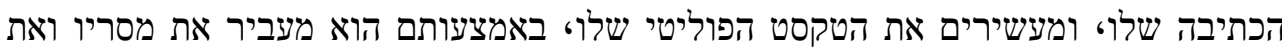

רעיונותיו לכל קהל הנמעל המירים.

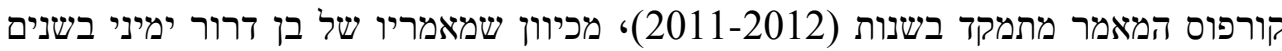

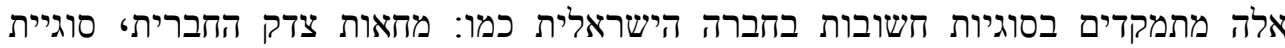

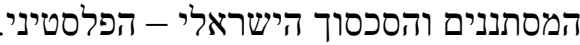

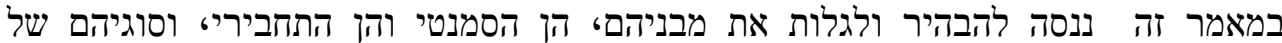

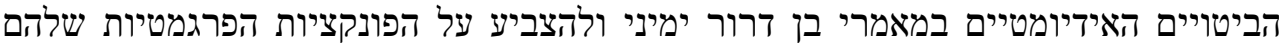

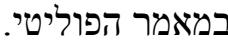
המחקר מתחלקים לשני חלקים، תיאורטי ויישומי، החלק התיאורטי כולל מבוא על הגדרותיו

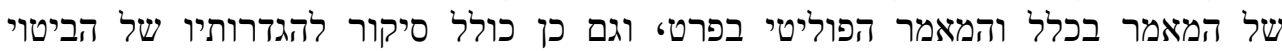

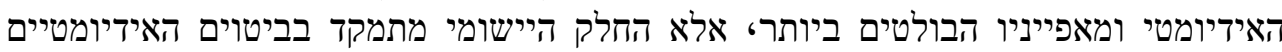

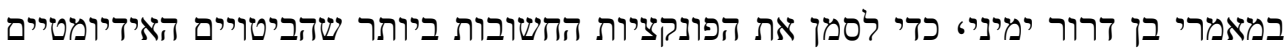
משחקים במאמר הפוליטי. חשיבות המחקר המת המרים הלשון היא הבסיס של כל תרבות، ובליבה של כל לשון נמצאים הביטויים האידידיומיומטיים،

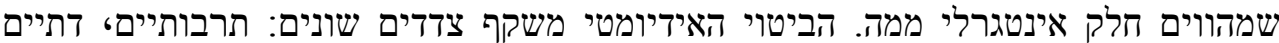

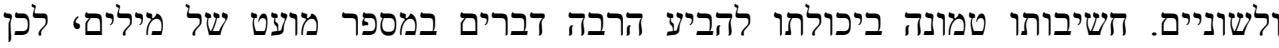

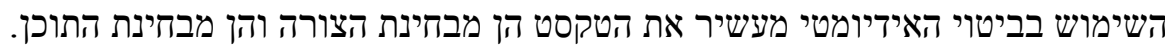

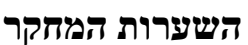

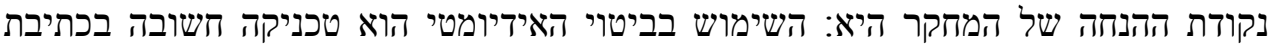
המאמר בכלל והפוליטי בפרט. הביטוי האידיומטי משחק תפקידידים חשידומטי חשובים רבים המסיבה בכתייעים

$$
-\varepsilon \cdot 9-
$$




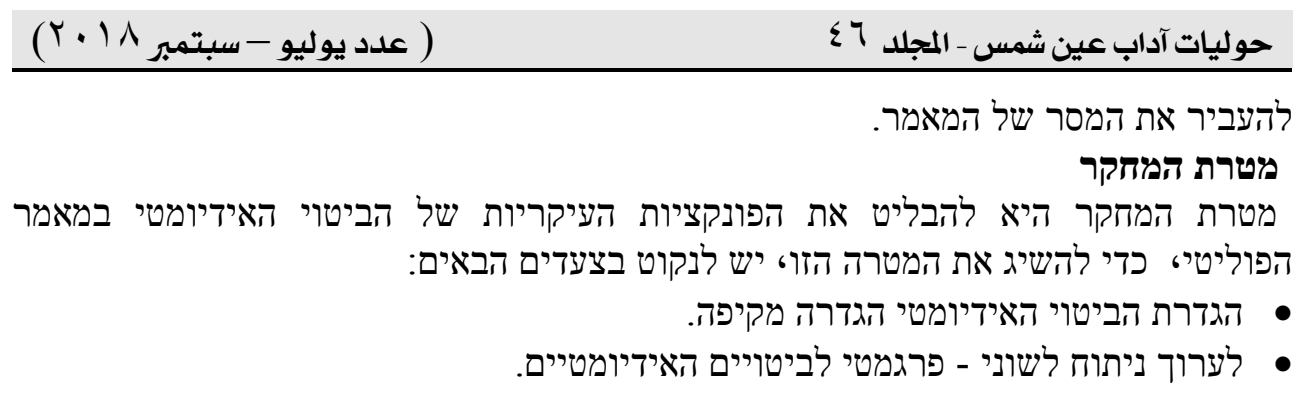

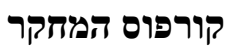

קורפוס המחקר מתהווה מהפ(100) ביטויים אידיומיומיים שמצויים ב (2012) מאמר של בן דרור ימיני، המפורסמים באתר עיתון "מעריב" הישראלי בשנת 2011-2012.

שיטת המחקר

כדי לנתח את הביטויים האידיומטיים מבחיטינה המיטה לשונית ולהבליט את הפונקציות העיקריות של הביטויים، נשענו על השיטה האנליטית והדסקריפטיבית.

•

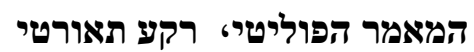

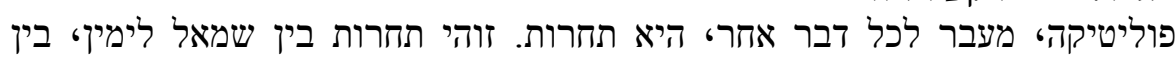

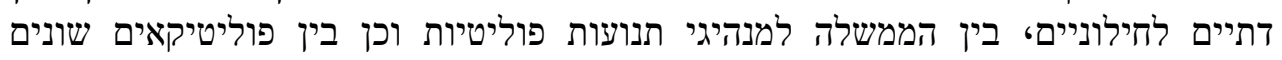

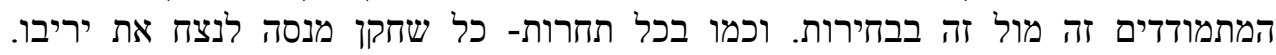

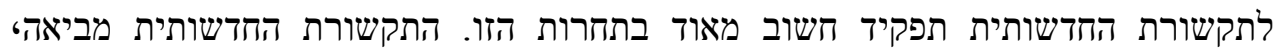

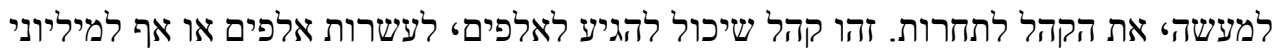

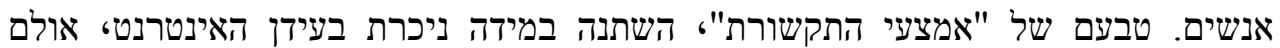

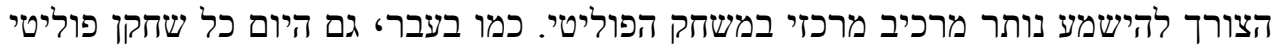

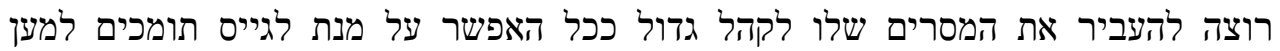

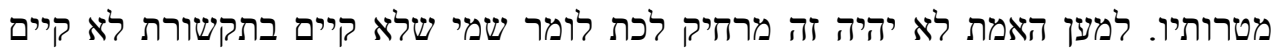

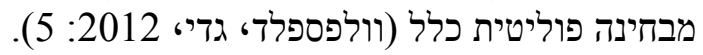

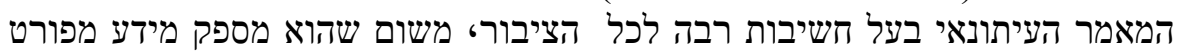

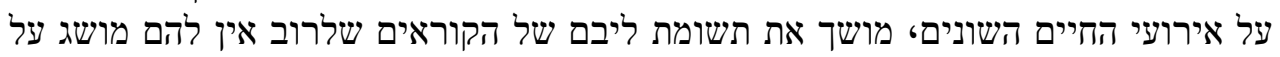

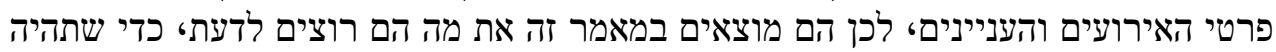

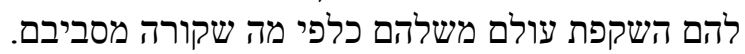

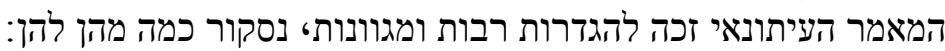

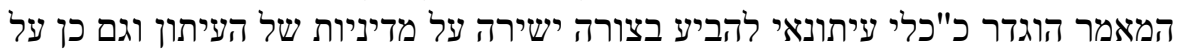

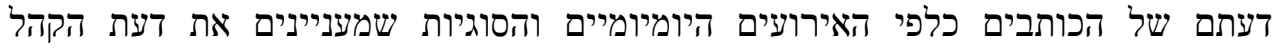

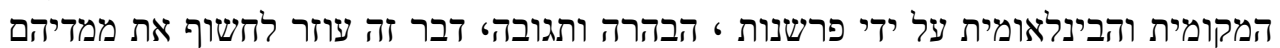

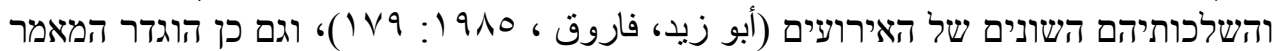

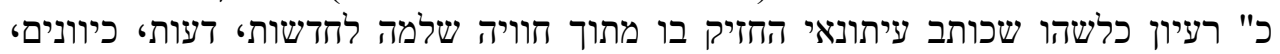

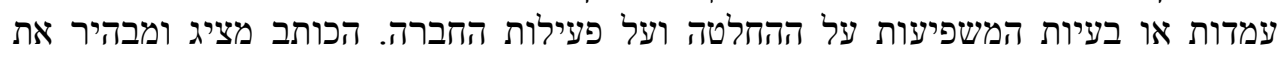

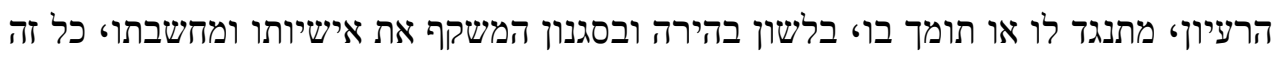

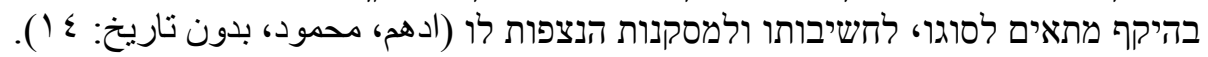

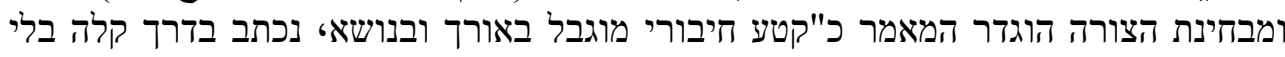

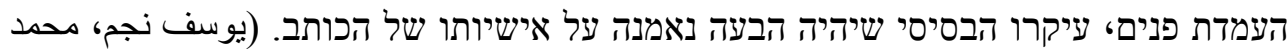

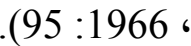

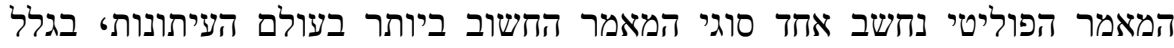

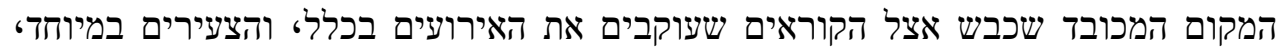

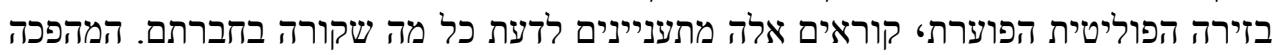

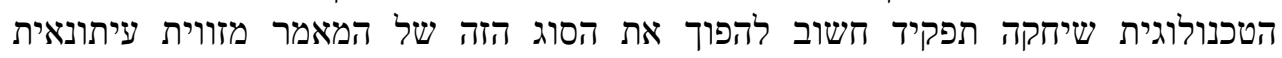




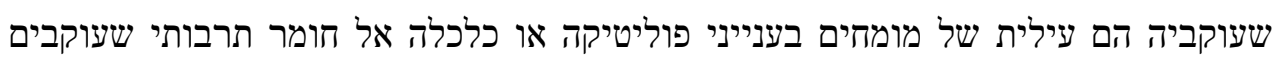

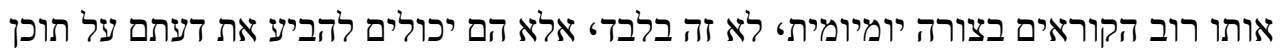

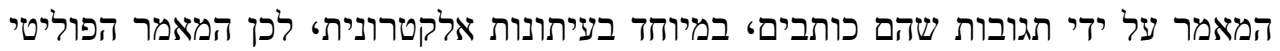

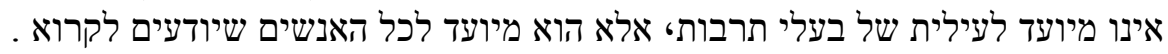

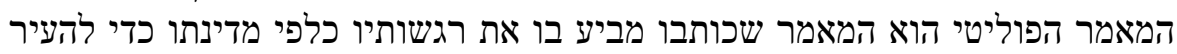

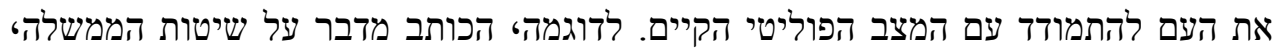

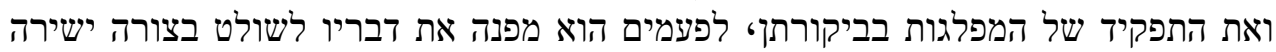

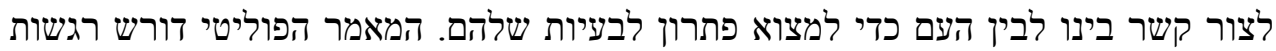
לאומיות נאמנות ותוכן לאומי נלהב שיכול להשפיע על לי הקוראים שלים (الحديدي، عبد اللطيف

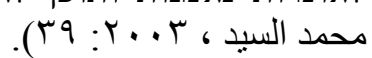

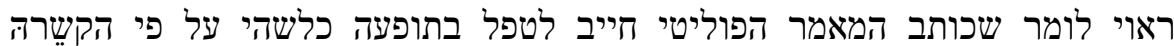

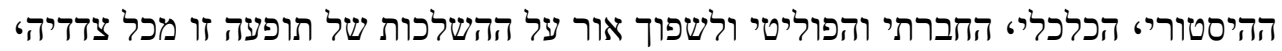

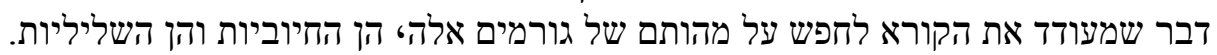

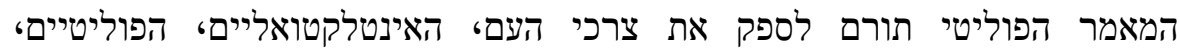

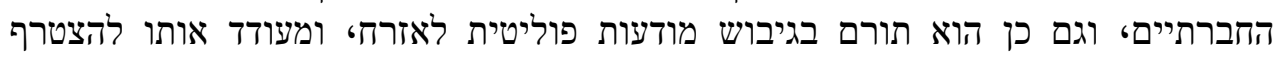

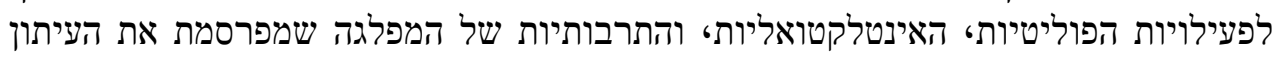

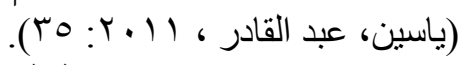

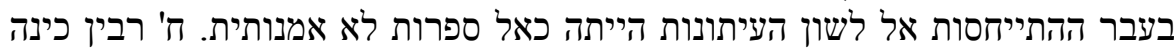

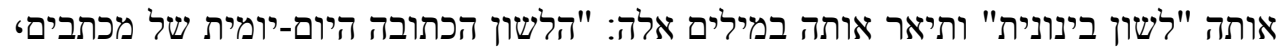

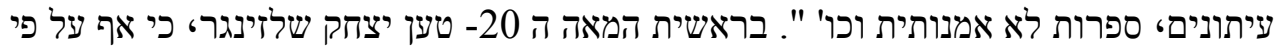

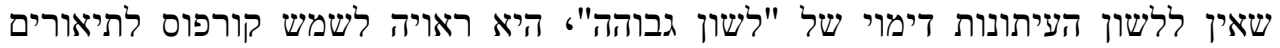

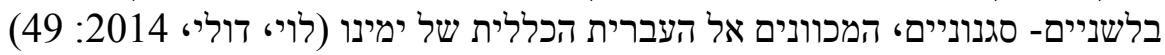

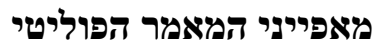

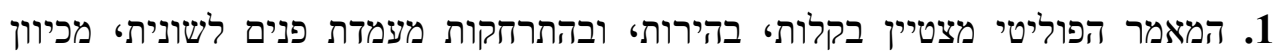

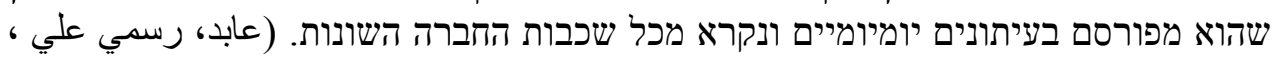

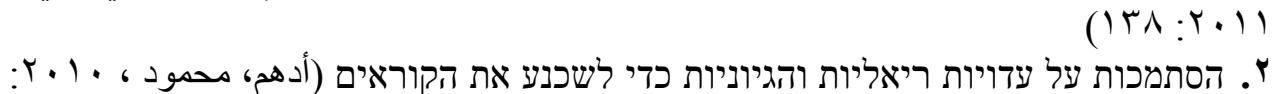

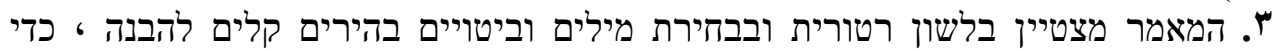

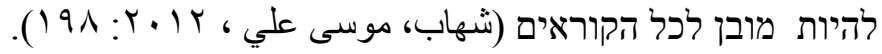
4. התוכן של המאמר נובע מהמציאות הקיימת של של החברהי כלומרי אוּי הדיון בבעיות של

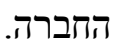

5. הצגת פתרונות מתאימות לבעיות שמוצגות במאמר.

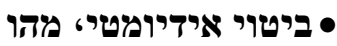

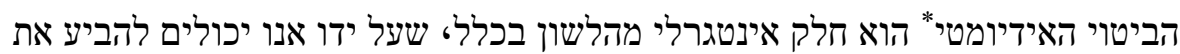

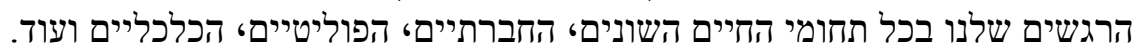

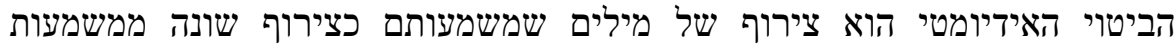

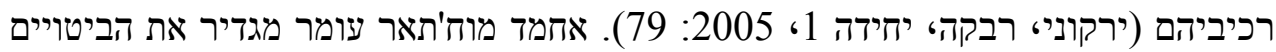

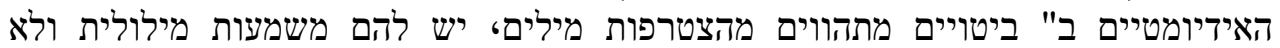

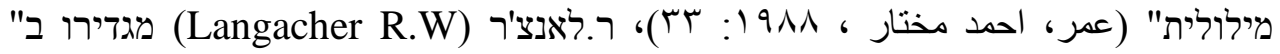

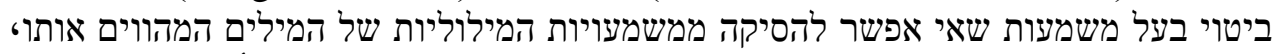

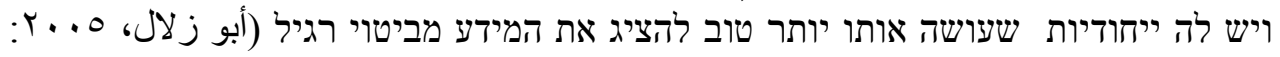

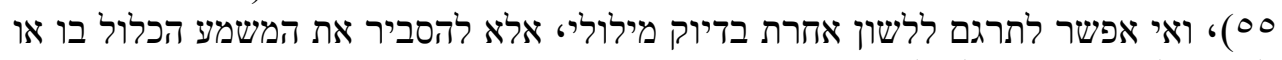

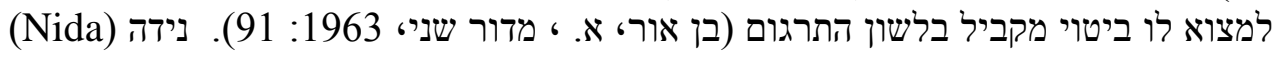
מציין שהקשר בין רכיבי הביטו האידיומטי אינוּי תורי תוצרה של הצטרפות רכיביוי ולכן יש 


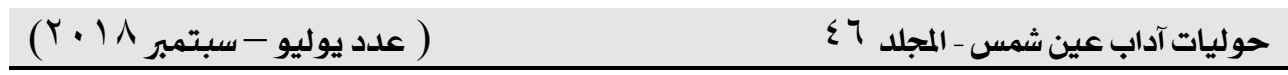

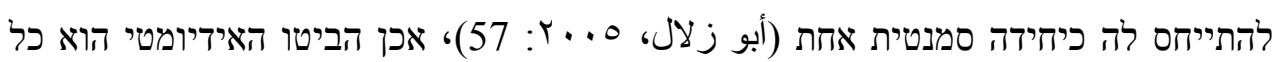
רצף של מילים הנוטות להופיע יחד ובסדר קבוע (בן שחרי רינהי (5) אכיז 1190: 101).

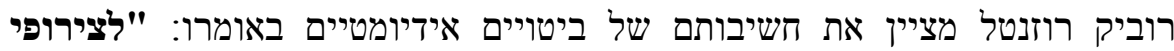

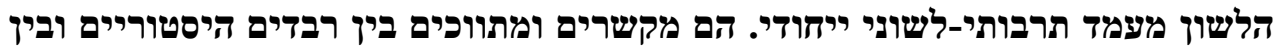

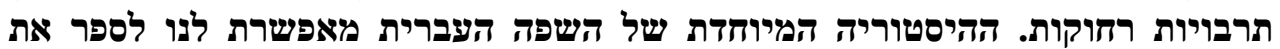

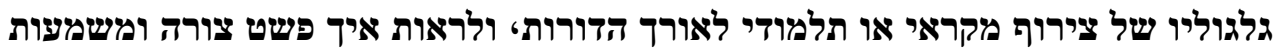

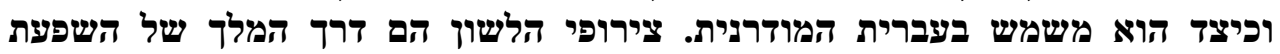

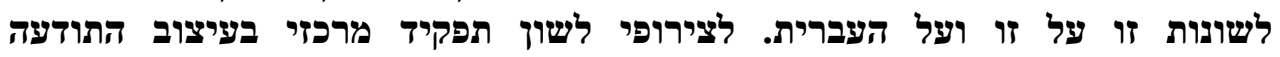

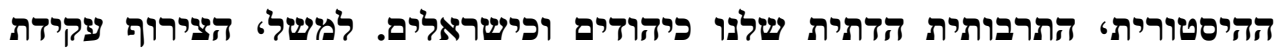

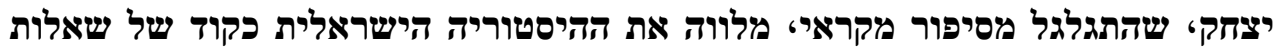

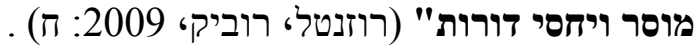

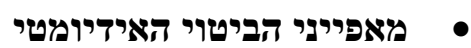

א. אידיומטיות: לפחות לאחת מן המילים המרכיבות את הצירוף יש משמעות שונה בתוך

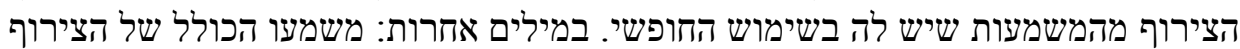

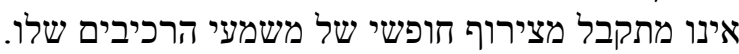

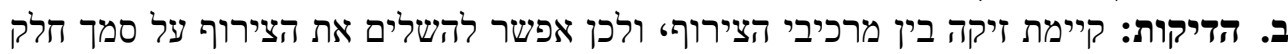

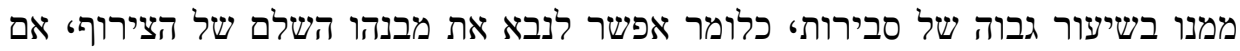
נתון חלק ממנו.

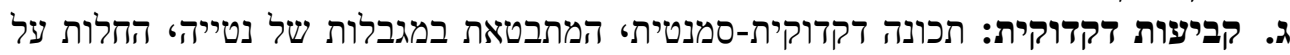

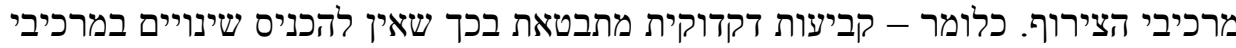

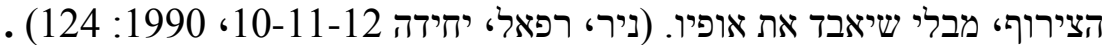

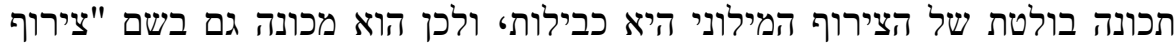

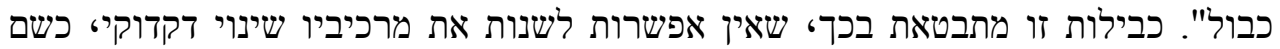

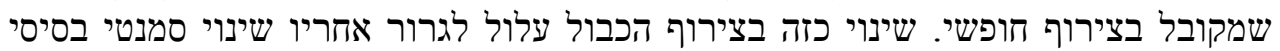

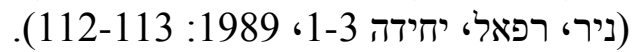

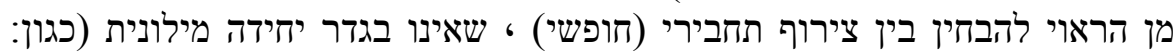

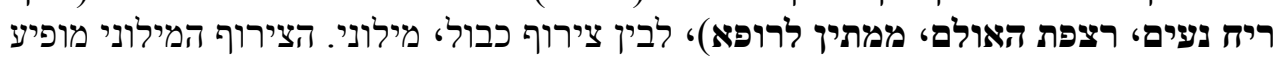

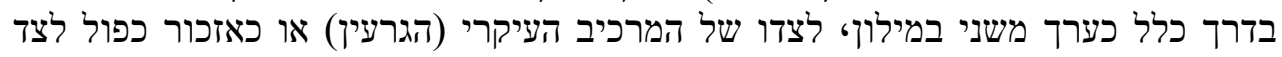

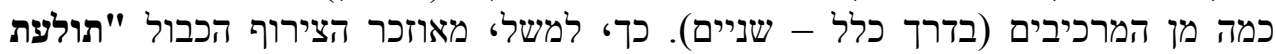

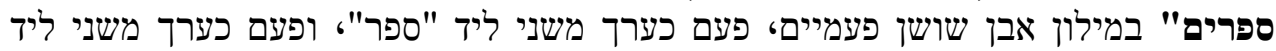

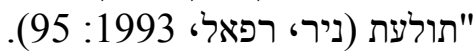
בינתיים עלינו לקבוע קריטריונים אחידים לצירופן של שתי מילים או להפרדתן،

ושניים הם : - בינתים

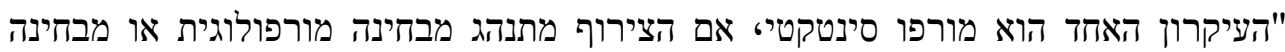

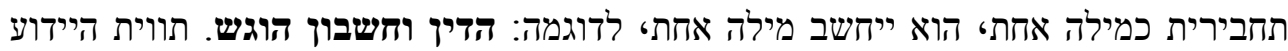

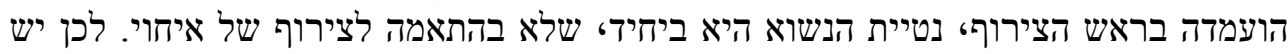

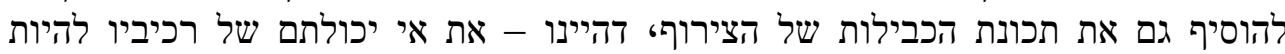

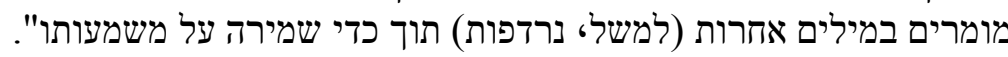

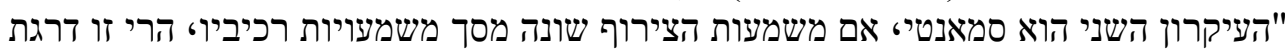

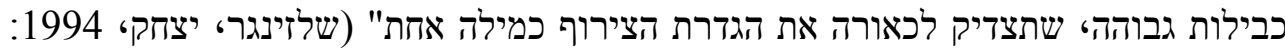

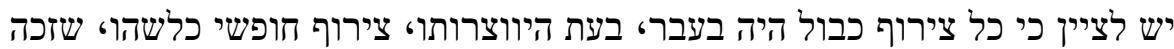
לשימושים חוזרים، עד כי שכחיות השימוש בו יצרה את כבילותו. מכאן שהמושג של של צירוף 


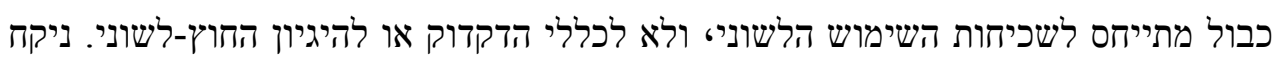

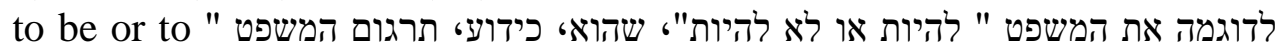

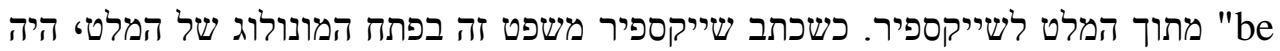

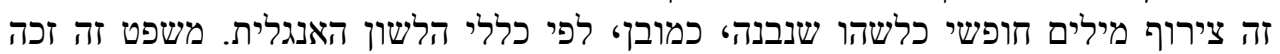

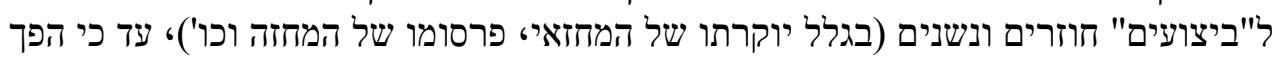

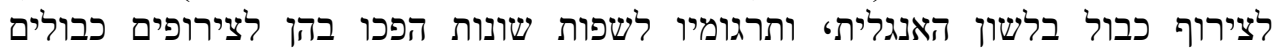

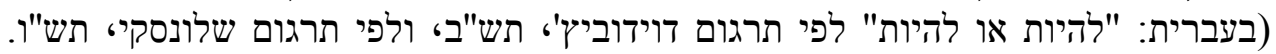

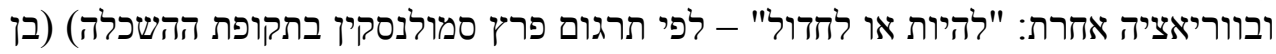

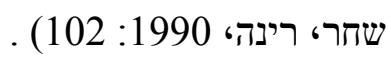

מאפיין נוסף של הביטוי האידיומטי הוא הארגון הדקדוקי הבלתי גמיש של רכיביביו.

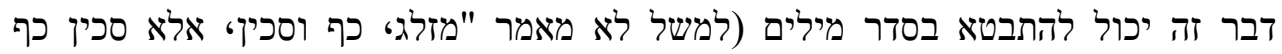

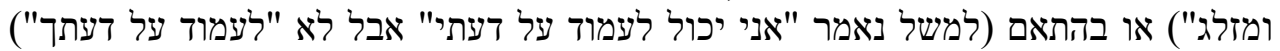

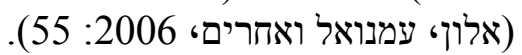

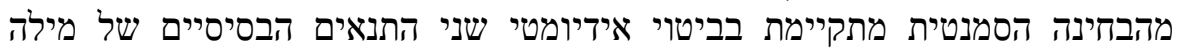

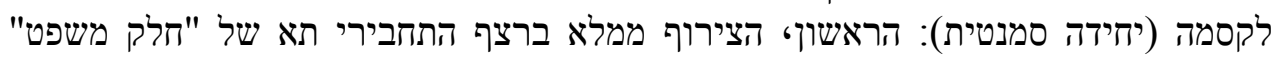

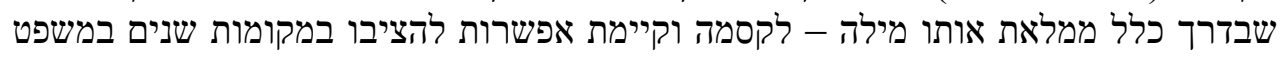

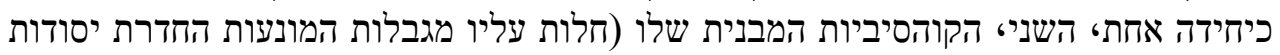

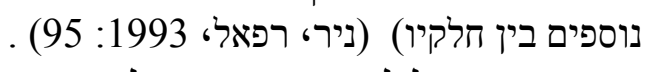

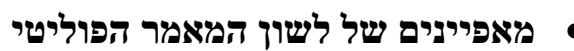

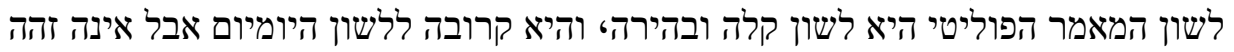

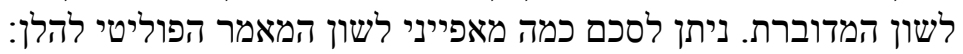

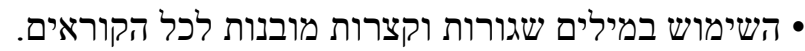

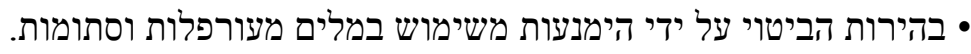

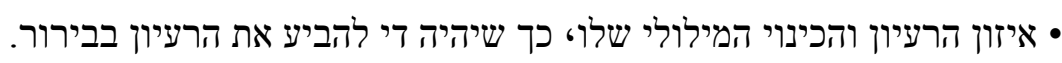

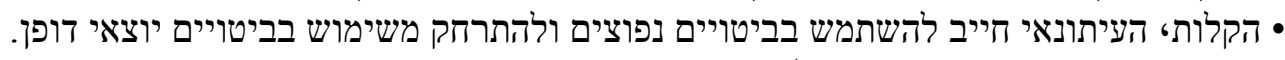
• השימוש במשפטים קצרים כביכול.

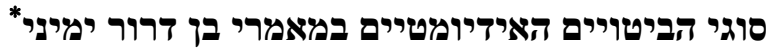 הביטויים האידיומטיים מתחלקים לארבע חלקים עיקרים הוריים:}

א. צרוים ואים

הוא שתי מילים או יותר הבאות יחד בקביעות ומהוות יחידה סמנטית ולקסיקלית،

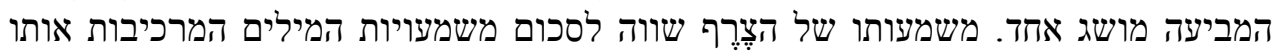

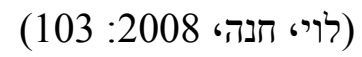

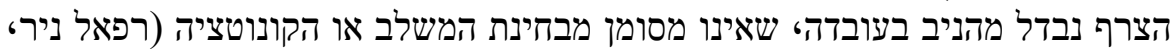

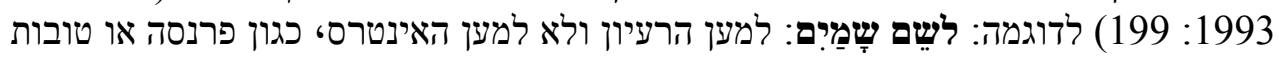

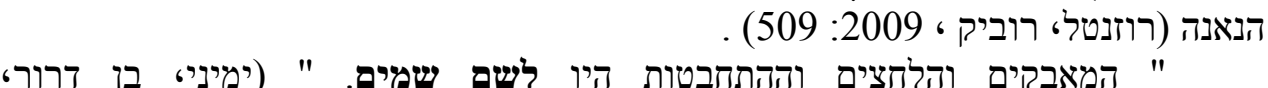
" המאבקים והלחצים וההתחבטות היו לשם שמים. " (ימיני، בן דרור، (12.1.2012 ‘www.nrg.co.il

ביטוי קבוע שמשמעותו אינה ניתנת לניבוי ממשמעות היחידות המרכיבות

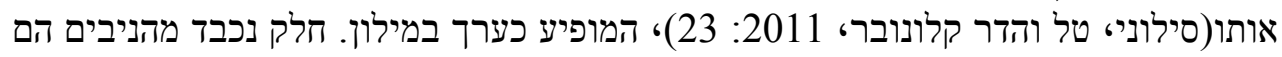

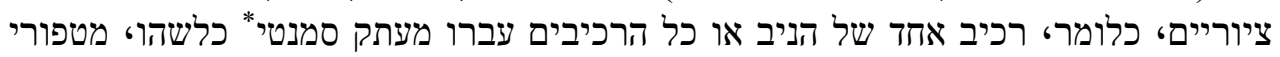

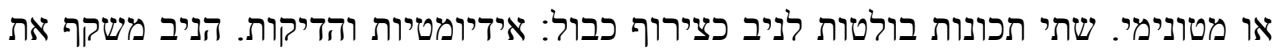

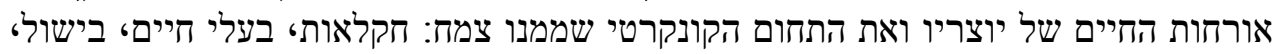


בנייה، מידות ומשקלות، דת، איתני הטבע וכו' (פרילוק، ניצהי 1999: 18-19)، לדוגמה

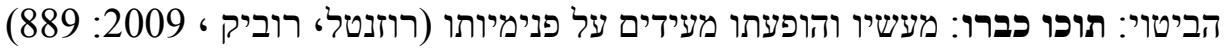

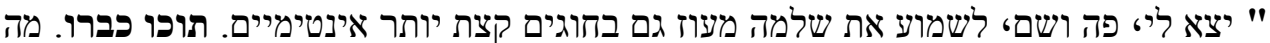

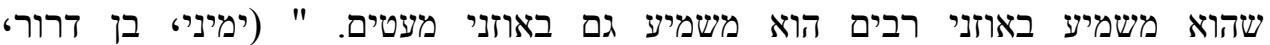

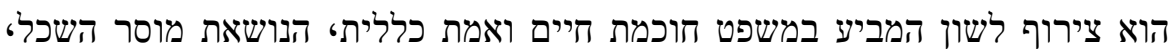

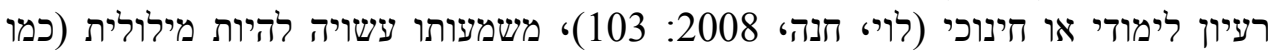

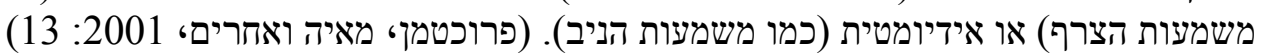

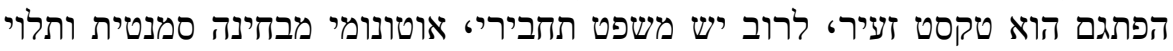

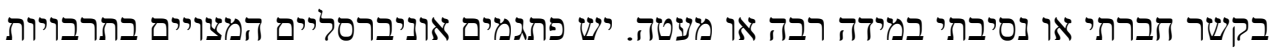
שונות، ויש פתגמים המוכרים ברברה מסוימתי כמו פתגמים פמים יהודים יהודיים הנשענים כל דת דת ועל

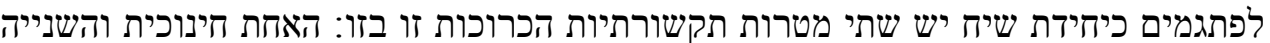

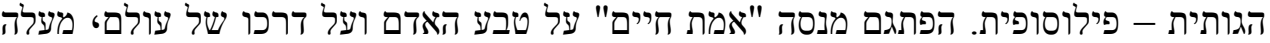

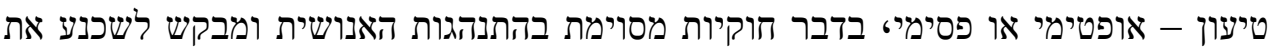

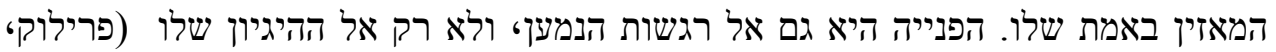

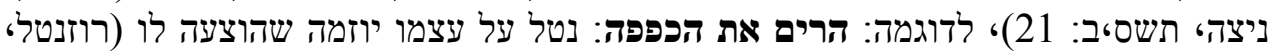
רוביק • 2009: 290).

" הכנסת חייבת להרים את הכפפה. לא כדי לפגוע בשלטון החוק. להפך. כדי להציל

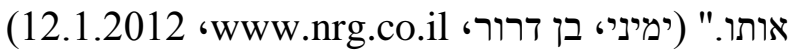

ד. משל

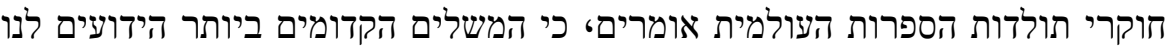

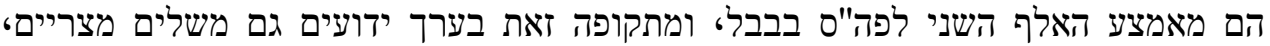

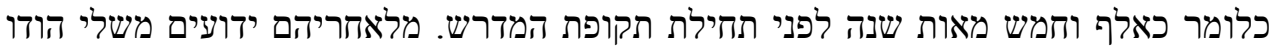
ומשלי איסוסופ היווני אשר מתועדות מן המאה השישית לפנה"ס (פרניתלי מלתלי יונהי 1996:

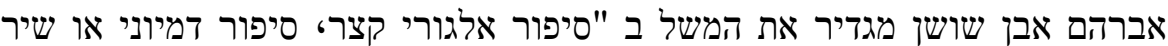

שיש בו מסר-השכלי מעשה בדוי העשוי לשמש דוגמה לאחרים" (אבן שושן، 1979:

המשל מצטיין בשלוש תכונות עיקריות הן:

א. השוואת שני דברים، שאחד מהם הוא המשלי והשיותי השי הנשל: נזם זהב באף חזירי אישה

יפה וסרת טעם.

ב. הבעה קצרה תמציתית המילים מעטות: פוטר מים רים ראשית משית מדון.

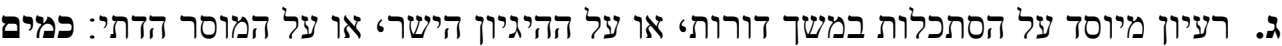

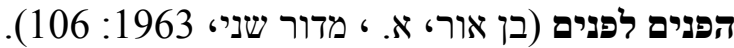

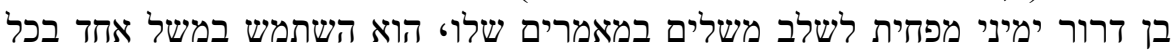

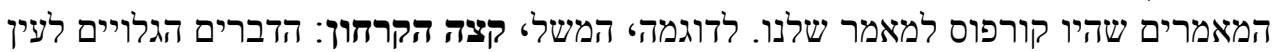

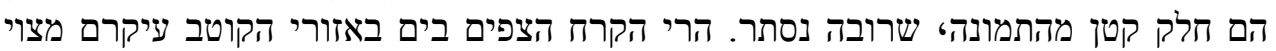

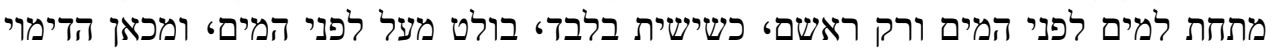

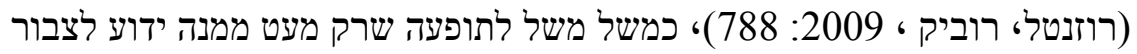

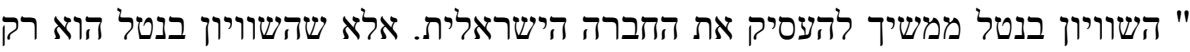

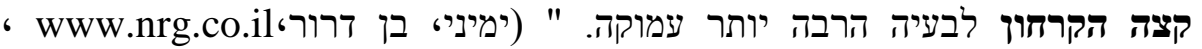




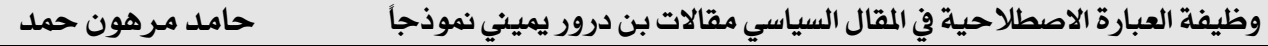 \\ • הצבנה התחבירי של הביטויים האידיומטיים במאמרי בץ דרור ימיני

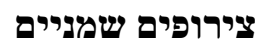

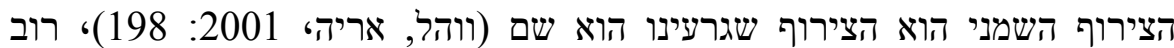

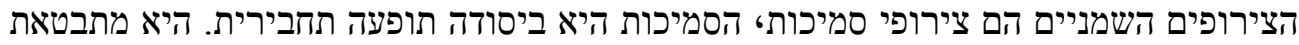

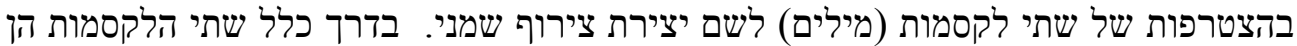

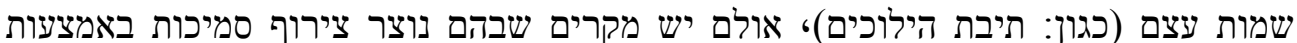

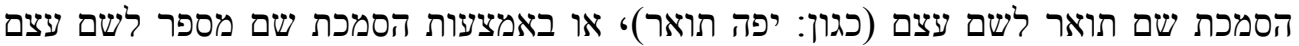

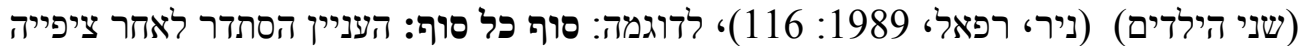

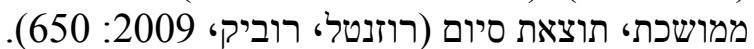
"החלטות הממשלה משלשום מצביעות עירות על כך שראש הממשלה סוף כל כל סוף סוף מתעורר

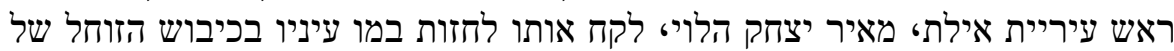

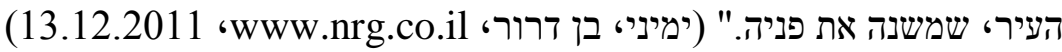

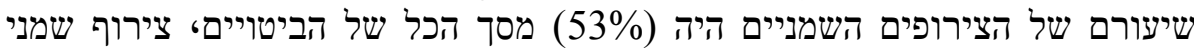
מסייע להבהיר או לנמק את דבריו של הכותב בוצרה פשוטה יחסיתי וגם כן שילובם בטקסט

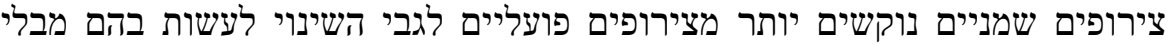

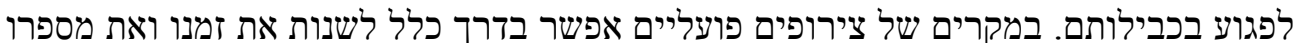

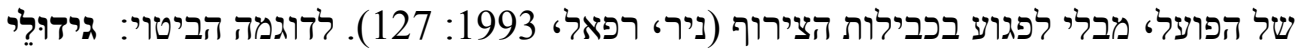

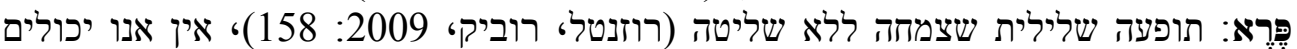

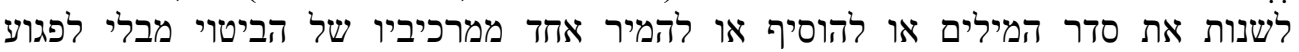

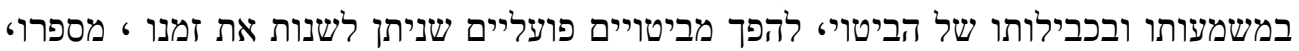

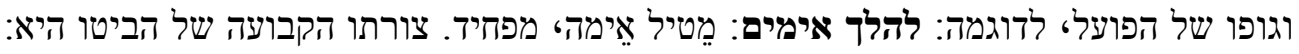

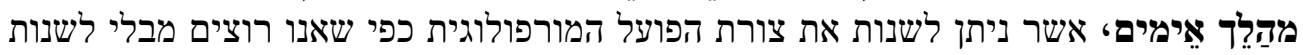
את משמעותו של הביטוי בכלל.

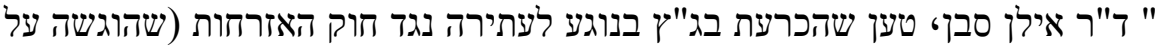

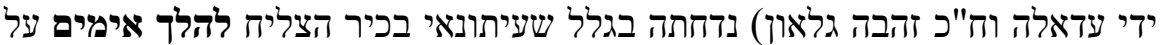

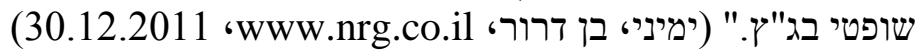

צירופים פועליים

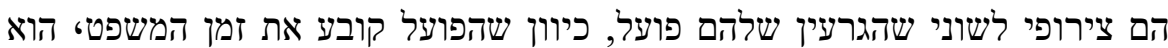

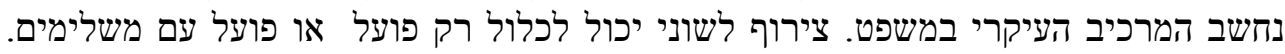

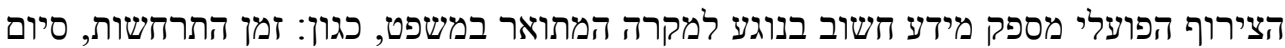

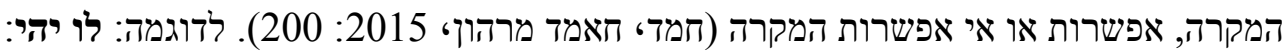

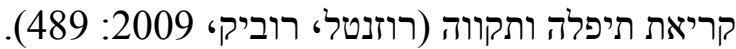

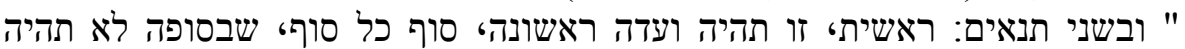

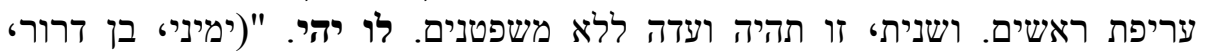

(12.2.2012 ، wwww.nrg.co.il שעיורם של הצירופים הפועליים זכה ל (16\%) מסך הכל של הביטויים، צירופים אלה מעצימים את האפקט של הטקסט ומוסיפים אווירה מותחת ודים ודינמית. מסר הכל

•

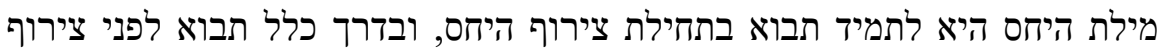

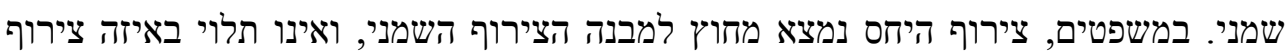

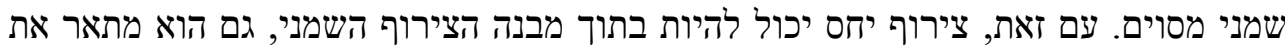

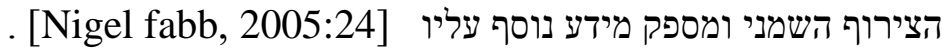


ניתן להגדיר את צירוף היחס ב: צירוף שיש בראשו מילת יחס ושם אחריה, כלומר

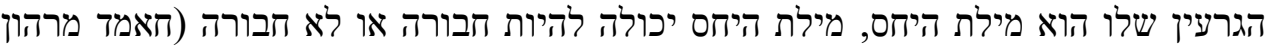

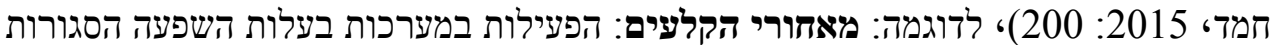

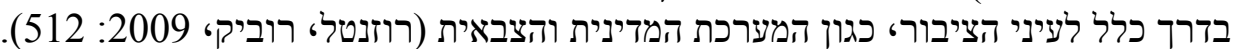

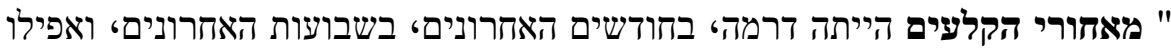

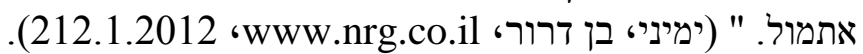

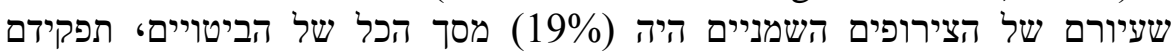
העיקרי של צירופים אלה הוא להוסיף ולהרחיב התים המים המדע בטקסט. מסכל

משפטים פשוטים ציקופים

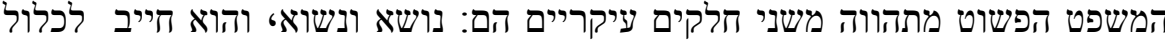

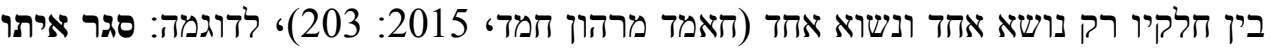
חשבון: לשלם את החוב של אחדי (סלנג) התנקםי השיב למישהו כגודי (חמולו (רוזנטלי רוביק 2006 2006

" לא מדובר רק בטענות פוליטיות. אלא שכל הטענות הללו מתגמדות מול העובדה לפורה

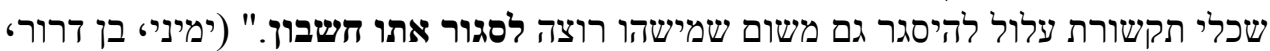

(28.8.2012 ،www.nrg.co.il שיעורם של המשפטים הפשוטים הוא (12\%) מסך הכל של הביטיטויים. יש לעיתים

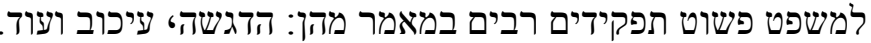

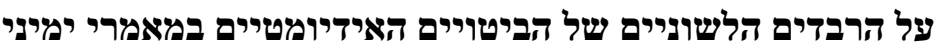
יש ארבעה מקורות עיקריים בלשון העברית של הביטויים הויים האידיומיומטיים، שנקבעו על פי תקופות הלשון שהם נוצרו בהם:

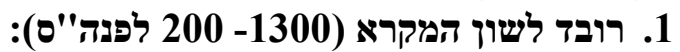

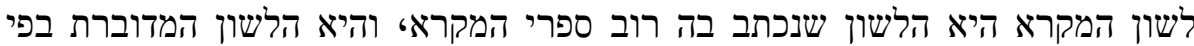

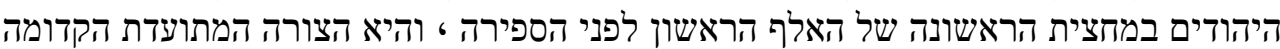
ביותר של השפה העברית.

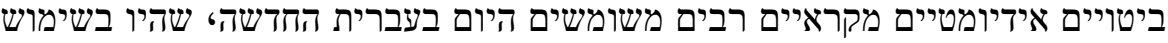

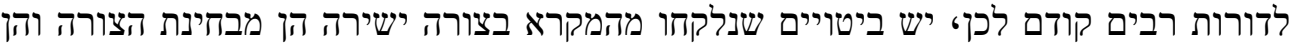

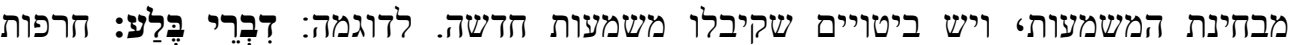

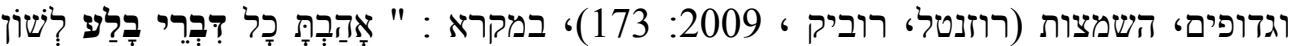

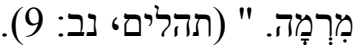

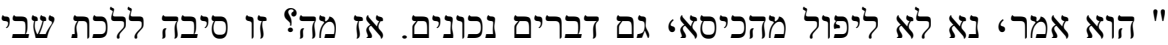
אחריו؟ זו סיבה להתעלם מדברי הבלע שה שהוא אומר? " "יפונים (ימיני، בן דרורי לכתי (4.9.2011 'www.nrg.co.il הביטויים שמקורם בלשון המקרא שיעורם הוא (28\%) מסך הכל של הביטויים، דבר

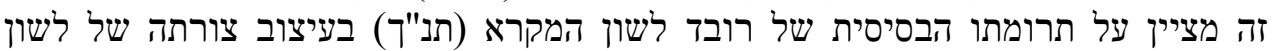
העברית בכלל והעברית המודרנית במיוחד.

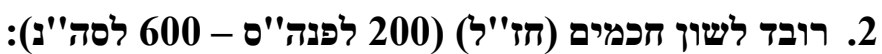

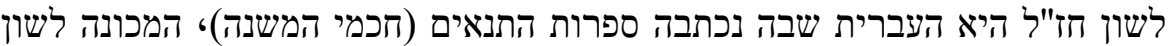
חכמים א'، וספרות האמוראים (חכמי התלמוד)، המכונה לשון חכמים הכים ב' (אלון המים עמנואל המכונה

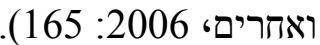

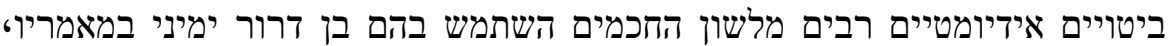

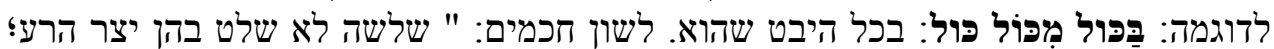

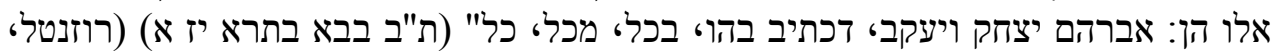


" הנשיאה، דורית ביניש6 דחתה את העתירה בכל שכל " (ימיני، בן דרור،

(16.12.2011 'www.nrg.co.il

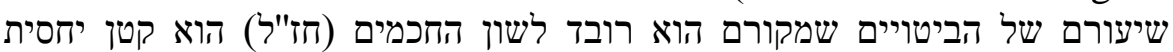

(15\%)، מכיוון שבן דרור ימיני משתמש בלשון עברית מודרנית שהשפעתה של לשון החוּל החז"ל

פחותה ביותר.

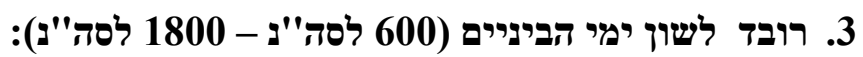

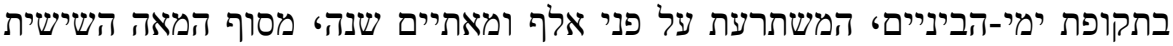

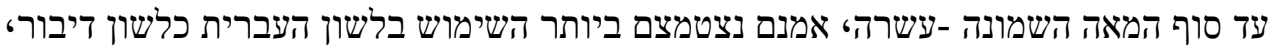

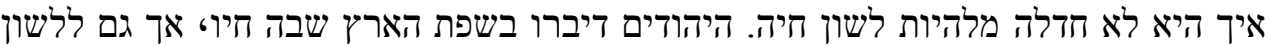

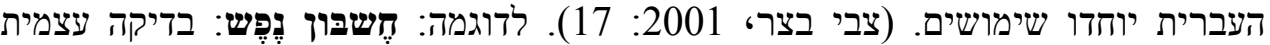

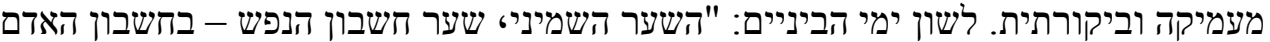

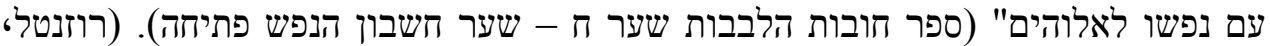

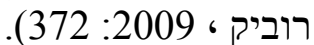
" אלא שחשבון נפש מחייב גם התבוננות בגידולי הפרא שצמחו בתוכנו. " (ימיני، בן

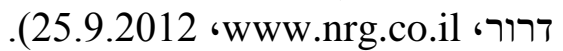

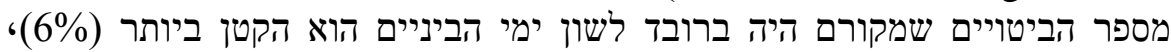

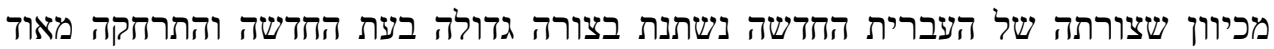

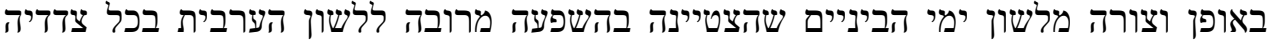

המורפולוגיים، הסמנטיים וצורה מהתוֹימי הביניים

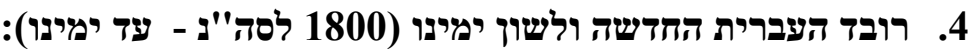

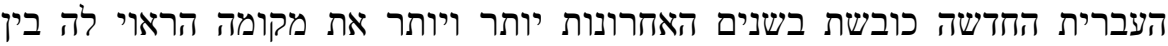

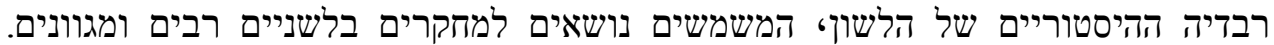

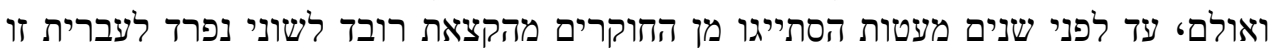

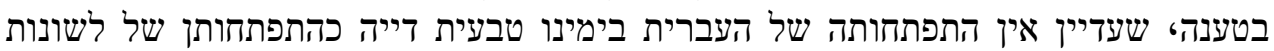

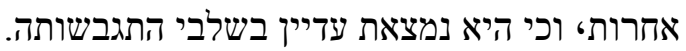

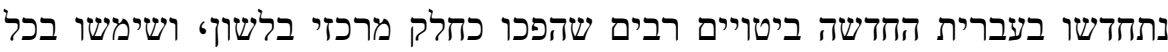

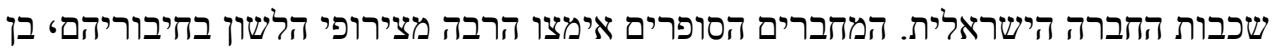

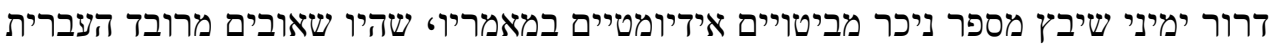

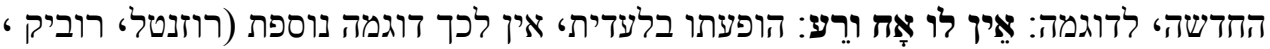

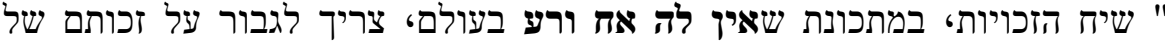

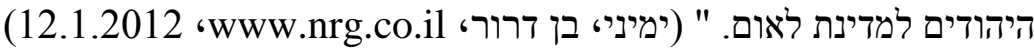

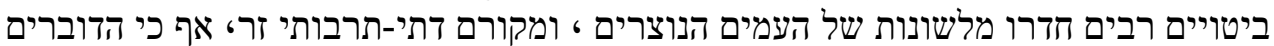

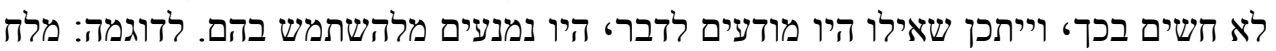

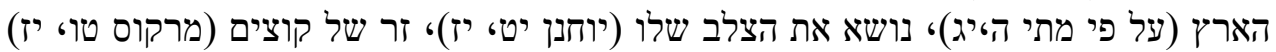

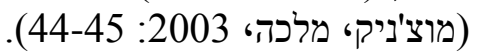

העברית החדשה שאלה ביטויים אידיומיומטיים רבים מלשונות זרות בדרכים שונים מונותי כדי

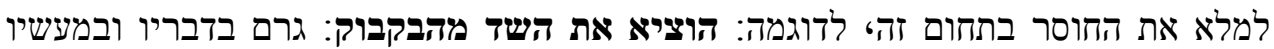

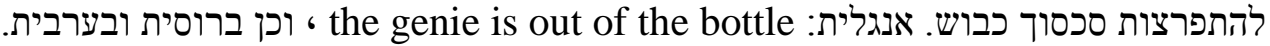

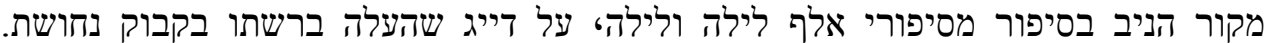

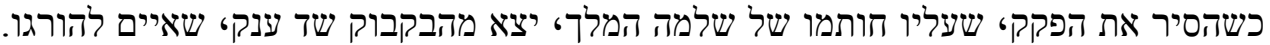

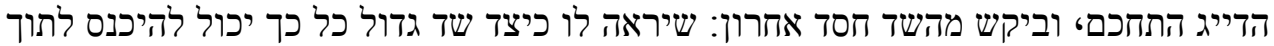

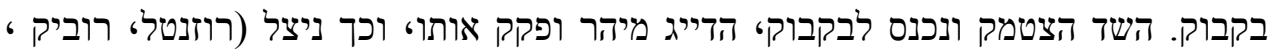


" ראשית، אין שום "שד עדתי"؛ והטענות נגד הגמוניה אשכנזית או בעד שוויון

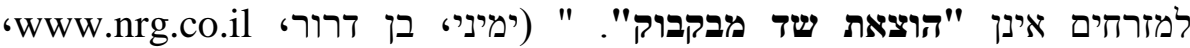

(17.1.2012

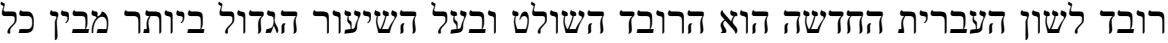

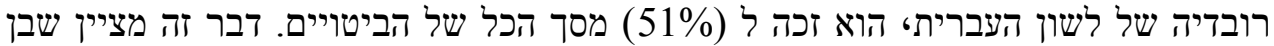

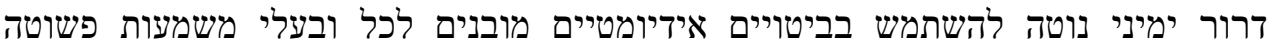

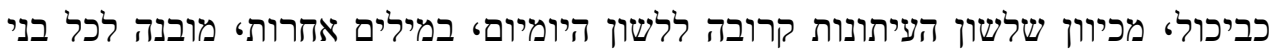
החברהי כדי להעביר את המסר שלה לכל הקונות העוראים לקון הקלות ובבהירותי במילים.

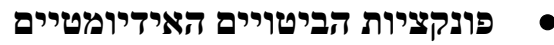

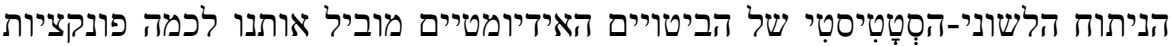

עיקריות ששיחקו במאמר שהן:

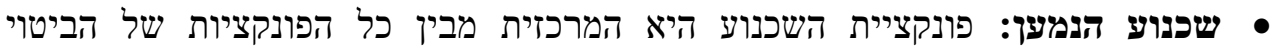

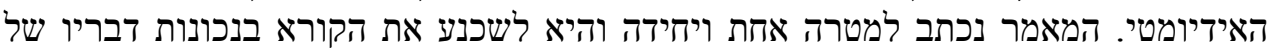

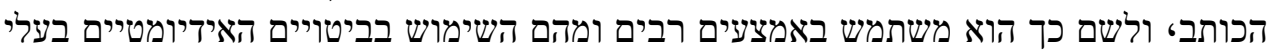

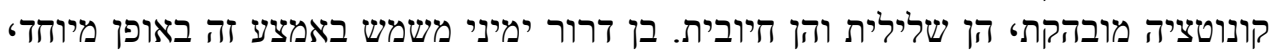

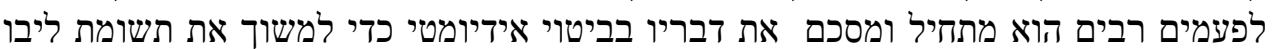

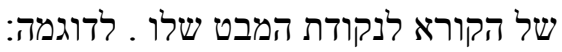

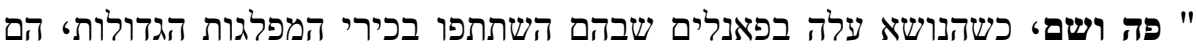

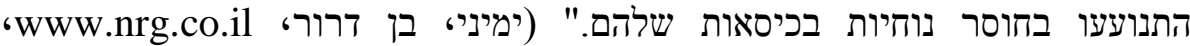

(14.2.2012

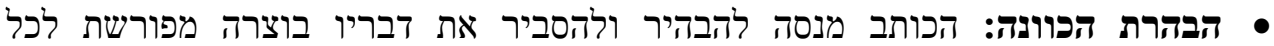

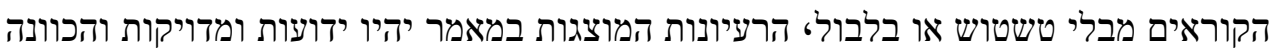

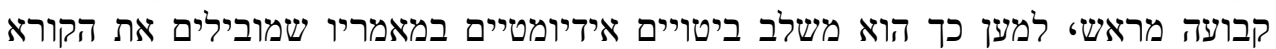

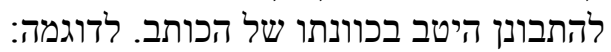

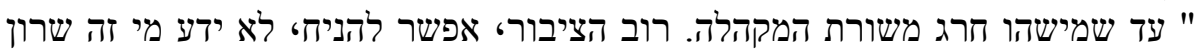

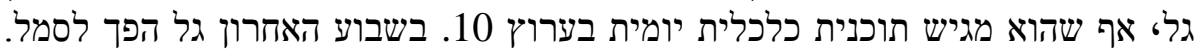

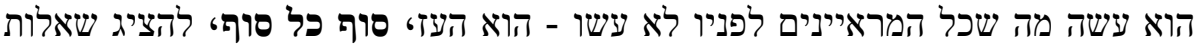

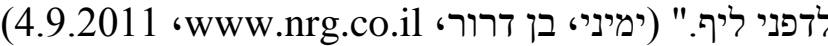

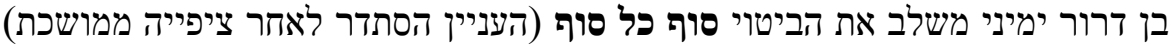

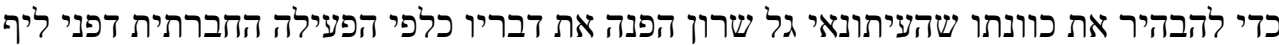

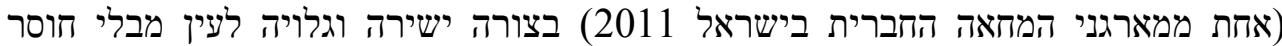

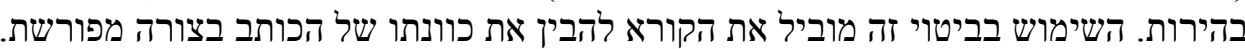

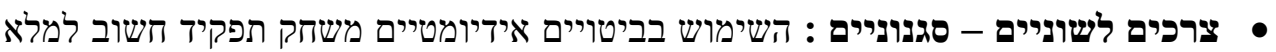

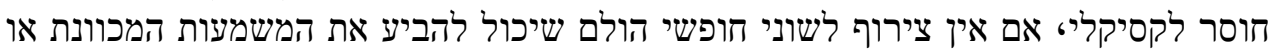

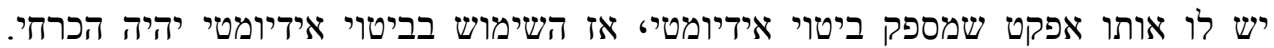

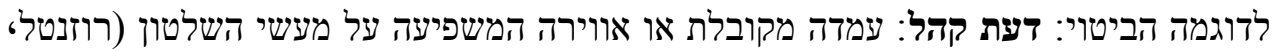

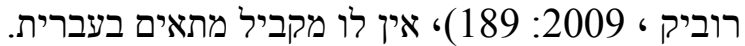
" אפשר להניח שאלה שהתקשרו אינם מייצי ביצים את כלית כלל דעת הקהלי אבל רק הם עלו

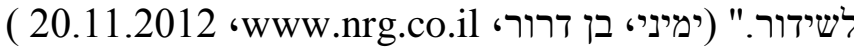

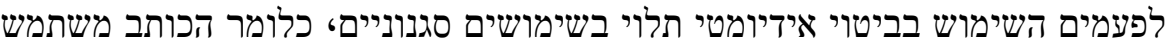

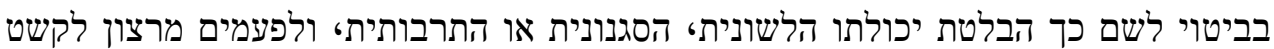

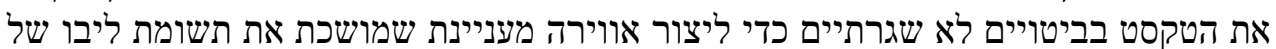




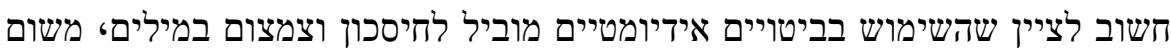

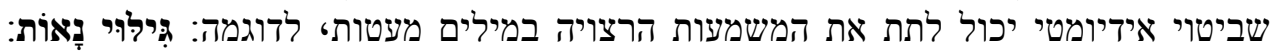

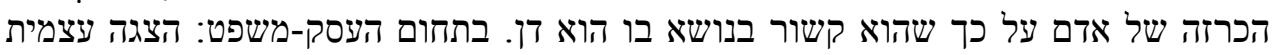

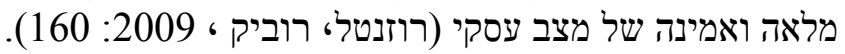

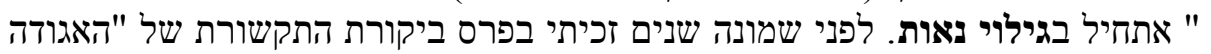

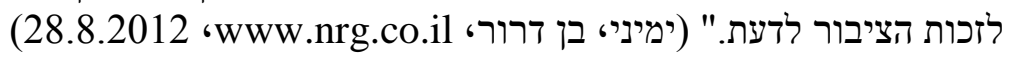

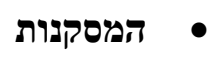

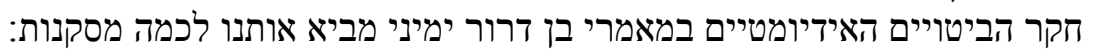

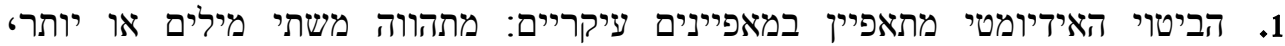

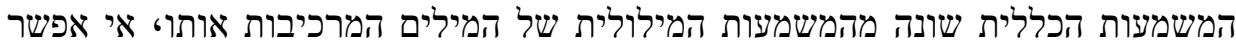

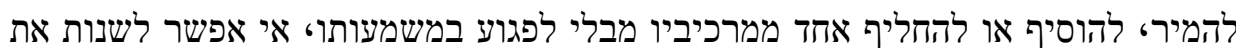
סדר המילים שלו.

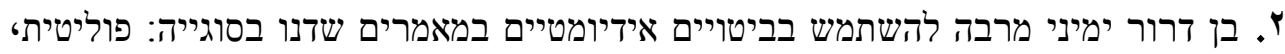

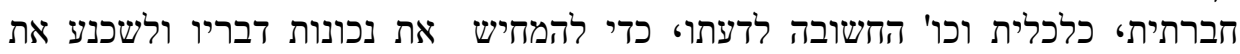
הקורא.

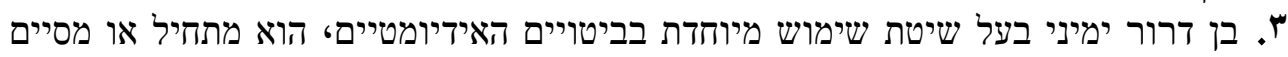

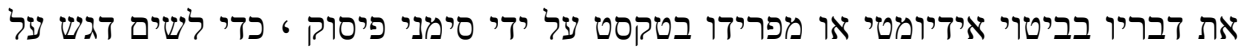

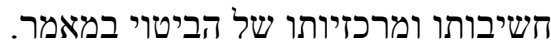

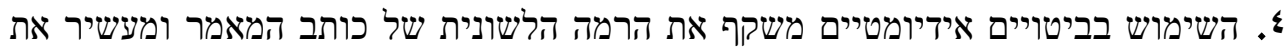

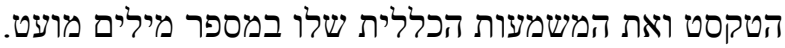

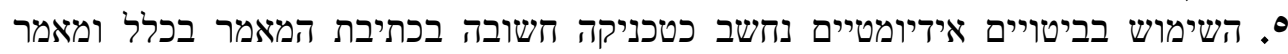

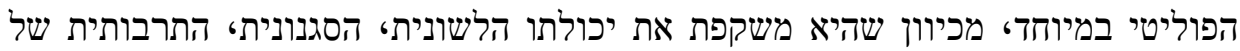

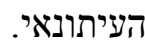

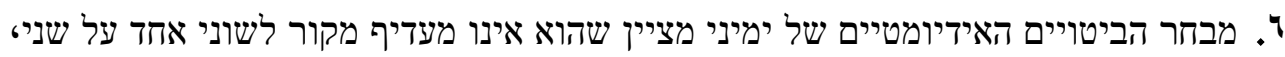

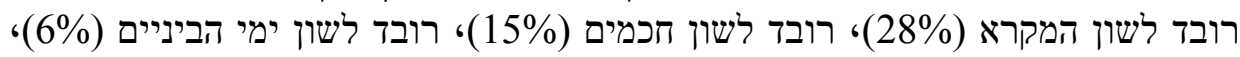
רובד העברית החדשה ובת ימים (28\%) רובינו (51\%).

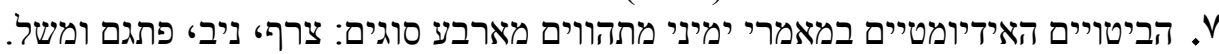

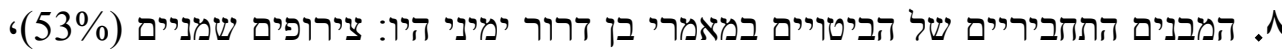
צירופים פועליים (16\%)؛ צירופים הביםים יחס (19\%) ומשפטים פשורים המוטים (12\%). 9. הביטויים האידיומטיים משחקים (16\%) פורופים פונקציות רבות במאמר הפוליטים מהן: שכנוע הנמעים

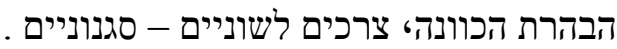

\section{רשימת המקורות}

\section{מקורות עבריים}

י. אבן שושן، אברהם (1979). המילון החדשי כרך שלישי، הוצאת קריית ספר בע"מ، ירושלים. ז. אלון، עמנואל ואחרים (2006). הטקסט הכתוב בעברית בת ימיפינוי מאפיינינים מבניים، תחביריים ולקסיקליים، הוצאת מכון מופים (196ים הופ"תי ישראל.

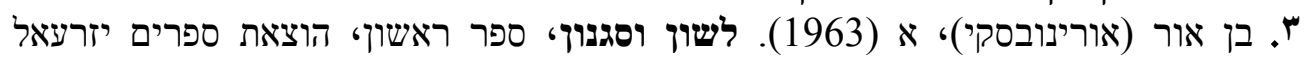
בע"מי תל־אביב. צ. בן שחרי רינה (1990). סגניבון הסיפורת, הלשון, הסגנון ולשון הספרות, יחידה 9-10, האוניברסיטה הפתוחה, תא אביב.

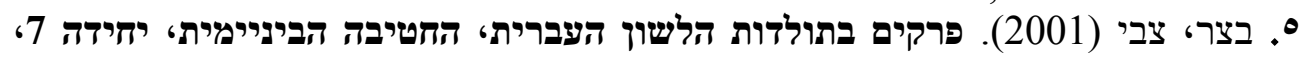
האוניברסיטה הפתוחהי תל אביב. צ. ווהלי אריה (2001). קריאה- תיאוריה הפוחיה ומעשה: לומדים ומלמדים אוריינות، כרך ב'، 


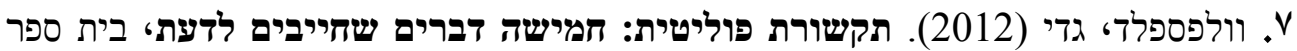
סמי עופר לתקשורת، המרכז הבינתחומי (204) הקורי הרצליה.

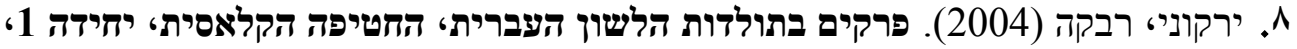
האוניברסיטה הפתוחהי תל־אביב. q. לוים דולי (2014). אפקטים קומיריים כסוגליבים (מאפיינינים) סגנוניים בכתיבתו העיתונאית

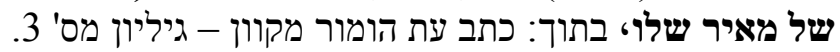

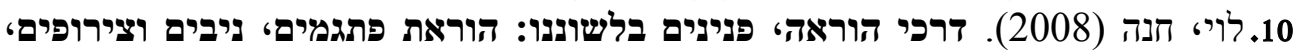

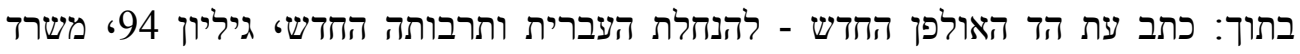

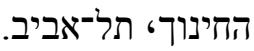
11. מוצ'ניקי מלכה (2003). לשון, חברה ותרבות, כרך ג' פרקים 7-8, האוניברסיטה

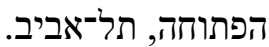
ז'ו. מרהון חמדי חאמד (2015). תפקיד הסלניג הישראלי בטרים בטרמינולוגיה הפוליטיתי עבודת

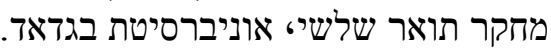
ז'ו. ניר، רפאל (1989): סמאנטיקתיקה עברית، משמעות ותקשורת، יחיזה 1-3 האוניברסיטה הפתוחה.

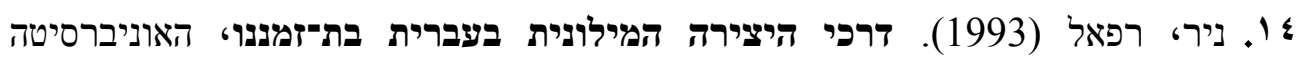

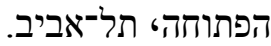
1.. ניר، רפאל (1993). מבוא לבלשנות، יחיזה 10-11-12، האוניברסיטה הפתוחהי תל־ אביב.

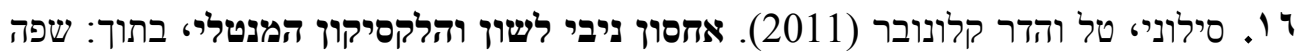

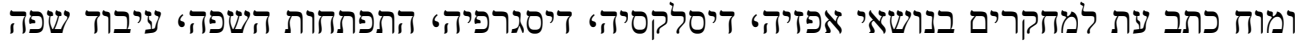

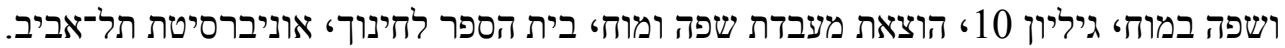

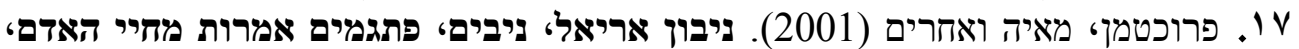

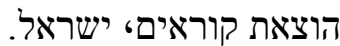

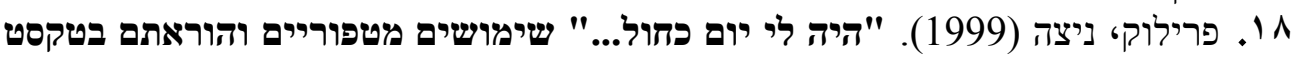

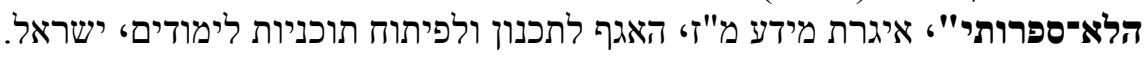

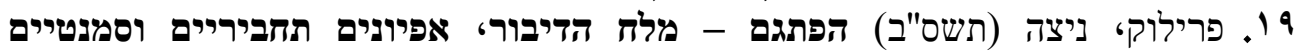

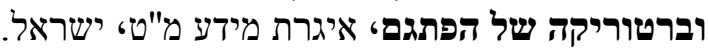

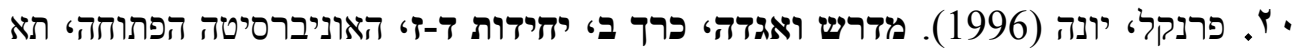

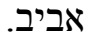
וץ. רוזנטלי רוביק (2006). מילון הסלנג המקיף، הוצאה לאור כתר، ירושלים، מהדורה רביעית. 22.רוזנטלי רוביק (2009). מילון הצירופיםים

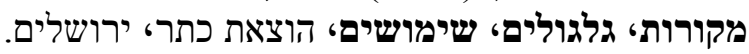
זץ. שלזינגרי יצחק (1994). פרקים בתולדות הלשון העון העברית، יחידה 11، האוניברסיטה

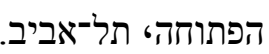
מקורות ערביים 1. . أبو زلال، عصام الدين عبد السلام (0 . . ب): التعابير الاصطلاحية بين النظرية و التطبيق، دار الوفاء لدنيا الطباعة و النشر ، الإسكندري.

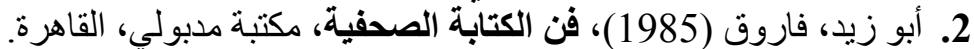

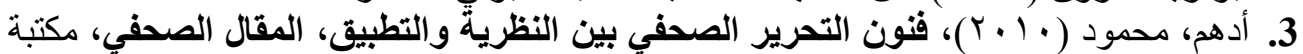

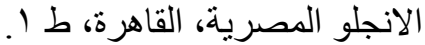
4. أدهم، محمود (بدون تاريخ): المقال الصحفي، مكتبة الأنجلو المصرية. 


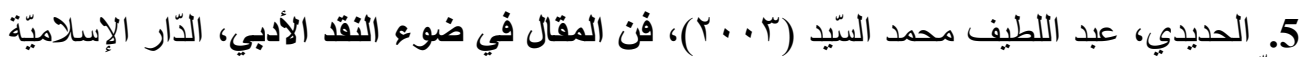

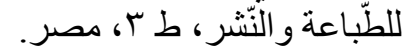

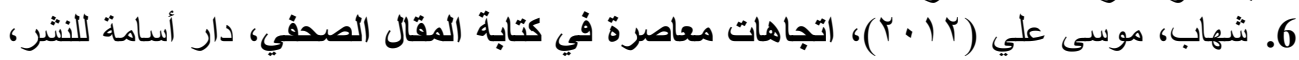

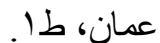
7. عابد، رسمي علي (11 (1)): مهارات التطبيقات الصرفية والإملاء والترقيم، دار يافا العلمية لاللنشر و التوزيع.

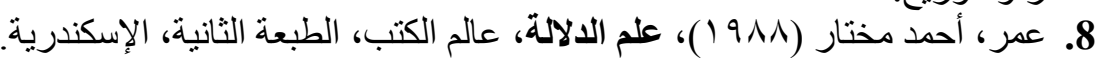

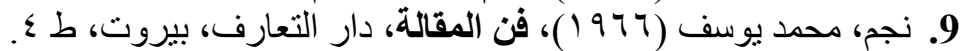

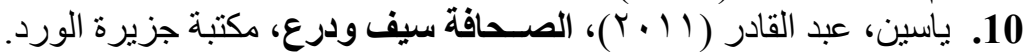

מקורות לועזיים

1. fabb ,Nigel (2005): sentence structure, second edition, publishing Rutledge, USA.

נספח: הביטויים אידיומטיים במאמרי בן דרור ימיפי

\begin{tabular}{|c|c|c|}
\hline תאריך & כותרת המאמר & ביטוי \\
\hline 27.3.2011 & אל תתנו להם מבצע & אֵין חַיָּה כָזֹאת \\
\hline 12.1 .2012 & אם חוק האזרחות היה נפסל - הייתה זו רעידת & אֵין לו אָח וררע \\
\hline 16.12 .11 & אויבי הציונות & אֵין עָָה לְדְאג \\
\hline 12.11 .2012 & אם חוק האזרחות היה נפסל - הייתה זו רעידת & אין שוּם סיבה למסיבה \\
\hline 8.11 .2011 & אימפריאליזם שיפוטי & אַל דְ ָָגָּה \\
\hline 16.12 .11 & אויבי הציונות & אנשי רוח \\
\hline 16.12 .11 & אויבי הציונות & 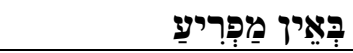 \\
\hline 16.12 .11 & אויבי הציונות & בַּפול מִכּוֹל \\
\hline 23.8 .2011 & באיזה צד שרה בסוגיית ההגירה? & בַכָל מִקרָרה \\
\hline 8.1 .2012 & הדיל שמנציח את הבעיה בעליון & בסופו של דבר \\
\hline 16.8 .2011 & אין צורך באויב & 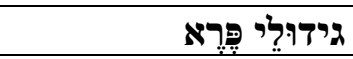 \\
\hline 28.8 .2012 & ביקורת התקשורת & 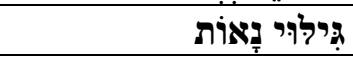 \\
\hline 28.8 .2012 & ביקורת התקשורת & דָָא עָקָָא \\
\hline 4.9 .2011 & אויבי המחאה & 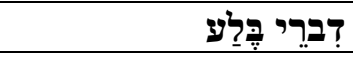 \\
\hline 16.12 .11 & אויבי הציונות & דִגֶל שָחוחור \\
\hline 8.5 .2012 & דין אחד לכולם & דיפי קפיין \\
\hline 20.11 .2012 & בכייני ההסברה & דַעַת הקָדָל \\
\hline 30.12 .11 & בזכות ההפרדה & זַרֵֵי פועַּם \\
\hline 17.1 .2012 & אין שדים & הוצאת נשד צבקבוק \\
\hline 25.9 .2012 & אשמנו، בגדנו، חטאנו: חשבון נפש לאומי & היה לא יהיה \\
\hline 21.6 .2012 & ביקורת הרסנית & הנדסת אנוש \\
\hline 12.2 .2012 & אל תתפטרו! & הַפְּקָת לְקָחים \\
\hline 14.2 .2012 & איוולת הפריימריז & הקו הירוק \\
\hline 12.1 .2012 & אם חוק האזרחות היה נפסל - הייתה זו רעידת & 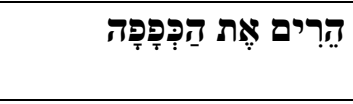 \\
\hline 3.4 .2012 & בגידת השמאל & 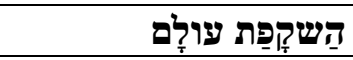 \\
\hline
\end{tabular}




\begin{tabular}{|c|c|c|}
\hline \multicolumn{3}{|c|}{ 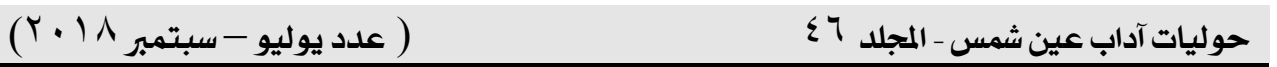 } \\
\hline 27.3 .2011 & אל תתנו להם מבצע & זרק אותו לקרשים \\
\hline 17.1 .2012 & הגזעענות המחאה "שד עדתית לאפליה אליה אלא בעצם & חבר מֵבְביא חָהֶר \\
\hline 25.9 .2012 & אשמנו، בגדנו، חטאנו: חשבון נפש לאומי & חֹד הַחְנִית \\
\hline 28.10 .11 & אביב הג'יהאד & תוּג הסילון \\
\hline 24.5 .2012 & אין הצדקה לאלימות שראינו בדרום תל אביב & 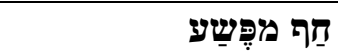 \\
\hline 25.9 .2012 & אשמנו، בגדנו، חטאנו: חשבון נפש לאומי & חעששבון נֶפֶשט \\
\hline 16.12 .11 & אויבי הציונות & טול קורה מבין עיניך \\
\hline 25.9 .2012 & אשמנו، בגדנו، חטאנו: חשבון נפש לאומי & 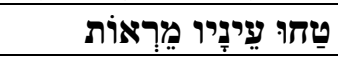 \\
\hline 28.10 .11 & אביב הג'יהאד & יד נעלמה יו: \\
\hline 13.12 .2011 & דמגוגיה דמוגרפית & יוצצִא לָאור \\
\hline 13.12 .2011 & דמגוגיה דמוגרפית & ירד האסימון \\
\hline 30.12 .11 & בזכות ההפרדה & ירחיק לכת \\
\hline 27.3 .2011 & אל תתנו להם מבצע & 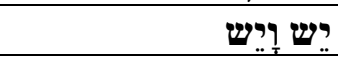 \\
\hline 30.12 .11 & בזכות ההפרדה & 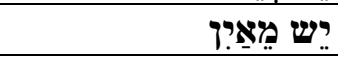 \\
\hline 20.3 .2012 & גיבוי נאור לטרור & 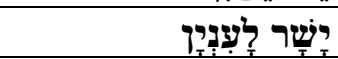 \\
\hline 3.4 .2012 & בגידת השמאל & 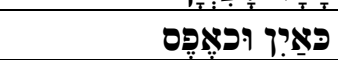 \\
\hline 12.2 .2012 & אל תתפטרו! & כבודו במקומו \\
\hline 28.10 .11 & אביב הג'יהאד & 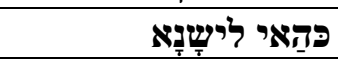 \\
\hline 12.4 .2012 & אשמת נתניהו & כָל הַכָבוּד \\
\hline 30.10 .2012 & ההתנצלות שלא הייתה & כָלְל כּוּלולה \\
\hline 13.12.2011 & דמגוגיה דמוגרפית & לְאוּ בַוְְְקָא \\
\hline 21.6 .2012 & ביקורת הרסנית & לגופו של עציין \\
\hline 30.12 .11 & בזכות ההפרדה & להלך אימים \\
\hline 12.2 .2012 & אל תתפטרו! & לו יהי \\
\hline 13.11 .2011 & דילמת הלגיטימציה & ללחוץ על הדוושה \\
\hline 4.9 .2011 & אויבי המחאה & ללכת שבי ה \\
\hline 28.8 .2012 & ביקורת התקשורת & לסגור אתו חשבון \\
\hline 25.9 .2012 & אשמנו، בגדנו، חטאנו: חשבון נפש לאומי & 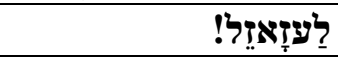 \\
\hline 28.8 .2012 & ביקורת התקשורת & לַעִפִִיוּת בַעתי \\
\hline 27.3 .2011 & אל תתנו להם מבצע & 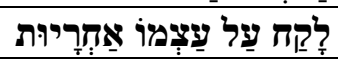 \\
\hline 12.1 .2012 & אדמה חוק האזרחות היה נפסל - הייתה זו רעידת & 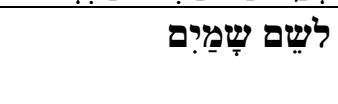 \\
\hline 12.1 .2012 & אם חוק האזרחות היה נפסל - הייתה זו רעידת & מֵאזחורי הקלְעים \\
\hline 17.7 .2012 & אקטיביזם מסוכן מימין & 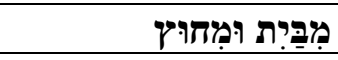 \\
\hline 4.9 .2011 & אויבי המחאה & מוצא חן \\
\hline 16.8 .2011 & אין צורך באויב & מחלות ילדות \\
\hline 28.10 .11 & אביב הג'יהאד & 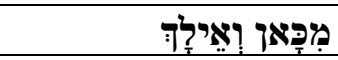 \\
\hline 9.8 .2011 & איך מונעים חורבן & 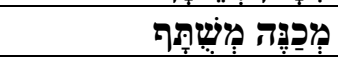 \\
\hline 12.4 .2012 & אשמת נתניהו & 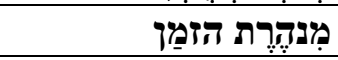 \\
\hline
\end{tabular}




\begin{tabular}{|c|c|c|}
\hline كامد مرهون حمد & \multicolumn{2}{|c|}{ وظيفة العبارة الاصطلاحية في المقال السياسي مقالات بن درور يميني نموذجاً } \\
\hline 12.4 .2012 & אשמת נתניהו & 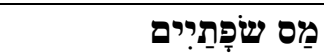 \\
\hline 17.7.2012 & אקטיביזם מסוכן מימין & 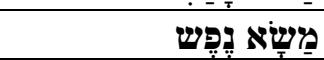 \\
\hline 20.11 .2012 & בכייני ההסברה & 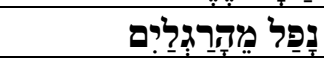 \\
\hline 13.12 .2011 & דמגוגיה דמוגרפית & 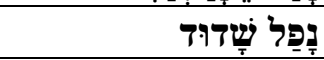 \\
\hline 12.1.2012 & אם חוק האזרחות היה נפסל - הייתה זו רעידת & 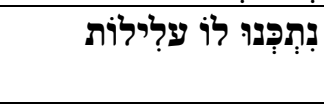 \\
\hline 25.9 .2012 & אשמנו، בגדנוי חטאנו: חשבון נפש לאומי & נָתַּן צֶת הַטּוֹן \\
\hline 28.10 .11 & אביב הג'יהאד & נתן היתר \\
\hline 3.4 .2012 & בגידת השמאל & סַדָנְּא דְאַרְָּּא חַד הוּא \\
\hline 24.5 .2012 & אין הצדקה לאלימות שראינו בדרום תל אביב & סדר יום \\
\hline 21.6 .2012 & ביקורת הרסנית & 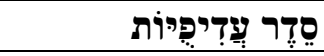 \\
\hline 13.12 .2011 & דמגוגיה דמוגרפית & סוף כָּל סוף \\
\hline 28.8 .2012 & ביקורת התקשורת & סימן דרך \\
\hline 30.12 .11 & בזכות ההפרדה & עועשֶה חַיִים \\
\hline 12.1 .2012 & אם חוק האזרחות היה נפסל - הייתה זו רעידת & על חוּדו של קול \\
\hline 16.8 .2011 & אין צורך באויב & עמצד עַל רַגרָליו \\
\hline 27.3 .2011 & אל תתנו להם מבצע & 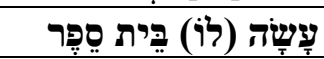 \\
\hline 14.2 .2012 & איוולת הפריימריז & פה ושם \\
\hline 8.1 .2012 & הדיל שמנציח את הבעיה בעליון & פועל יוצא \\
\hline 12.4 .2012 & אשמת נתניהו & 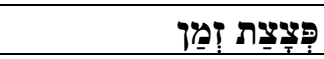 \\
\hline 28.8 .2012 & ביקורת התקשורת & זָּרה קדושה \\
\hline 16.12 .11 & אויבי הציונות & קו אדום \\
\hline 12.1 .2012 & אם חוק האזרחות היה נפסל - הייתה זו רעידת & קודש הקודשים \\
\hline 13.12.2011 & דמגוגיה דמוגרפית & קורֵעַ לִב \\
\hline 25.9.2012 & אשמנו، בגדנו، חטאנו: חשבון נפש לאומי & קורַת הַגג \\
\hline 25.9 .2012 & אשמנוי בגדנוי חטאנו: חשבון נפש לאומי & קצה הקרחון \\
\hline 16.12 .11 & אויבי הציונות & רוּח רָעצה \\
\hline 15.2 .2011 & אין הבדל בין "הרב" ליאור למסית משמאל & רוּטֵּה רוּח \\
\hline 17.1 .2012 & הגדרענות המחאה "שד עדתי" לאנות לאפליה אלא בעצם & ריבונו של העולם \\
\hline 30.12 .11 & בזכות ההפרדה & שׁעוּב רָּשּׁוּב \\
\hline 14.2 .2012 & איוולת הפריימריז & 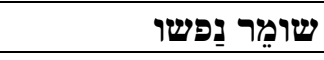 \\
\hline 8.11 .2011 & אימפריאליזם שיפוטי & שטטיפַַת מוחַ \\
\hline 17.7 .2012 & אקטיביזם מסוכן מימין & 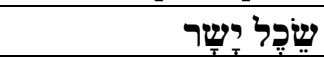 \\
\hline 28.10 .11 & אביב הג'יהאד & שפפיכוּת דָמים \\
\hline 21.6 .2012 & ביקורת הרסנית & 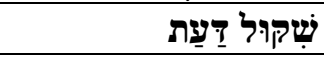 \\
\hline 17.1 .2012 & אין שדים & תוכו כָבָרו \\
\hline
\end{tabular}




\section{Abstract \\ The function of the idiomatic Expression in the political articles Ben-Dror Yemini, for example Study analysis - pragmatic Study \\ By HAMID MRHOON HAMD}

This research sheds lights on one of the important rhetorical linguistics methods, which is the idioms phrase and its use in the Israeli political article. By the studying of its most prominent types and different grammatical structures, and its deliberative function. The application of this study was the articles of the Israeli journalist Ben-Dror Yemini. Which were published on the website of Israeli newspaper " Maariv" in (2011-2012).

This research is divided into two devotions: theoretically and practically. The theoretical side included an introduction to identify the article generally, and the political article. Practically with a review of the most important definitions concerned with the idioms phrase and showing its most important features. The practically sides interested in observation of the most prominent types of the idioms phrase and its grammatical structures in articles of Ben-Dror Yemini in order to reach to the most important deliberative functions performed by idioms phrase in political article.

The research finds that the idioms phrase has its own lexical semantic and grammatical structure can't be compromised without prejudice to the general meaning of the idioms phrase and also find that the most prominent grammatical structures of the idioms phrase in Ben-Dror Yemini articles were (the nominal phrase, the verbal phrase prepositional phrase and simple phrase).

The most prominent functions performed by idioms phrase are: convince the receiver, demonstrate of intention and different linguistics and stylistic functions.

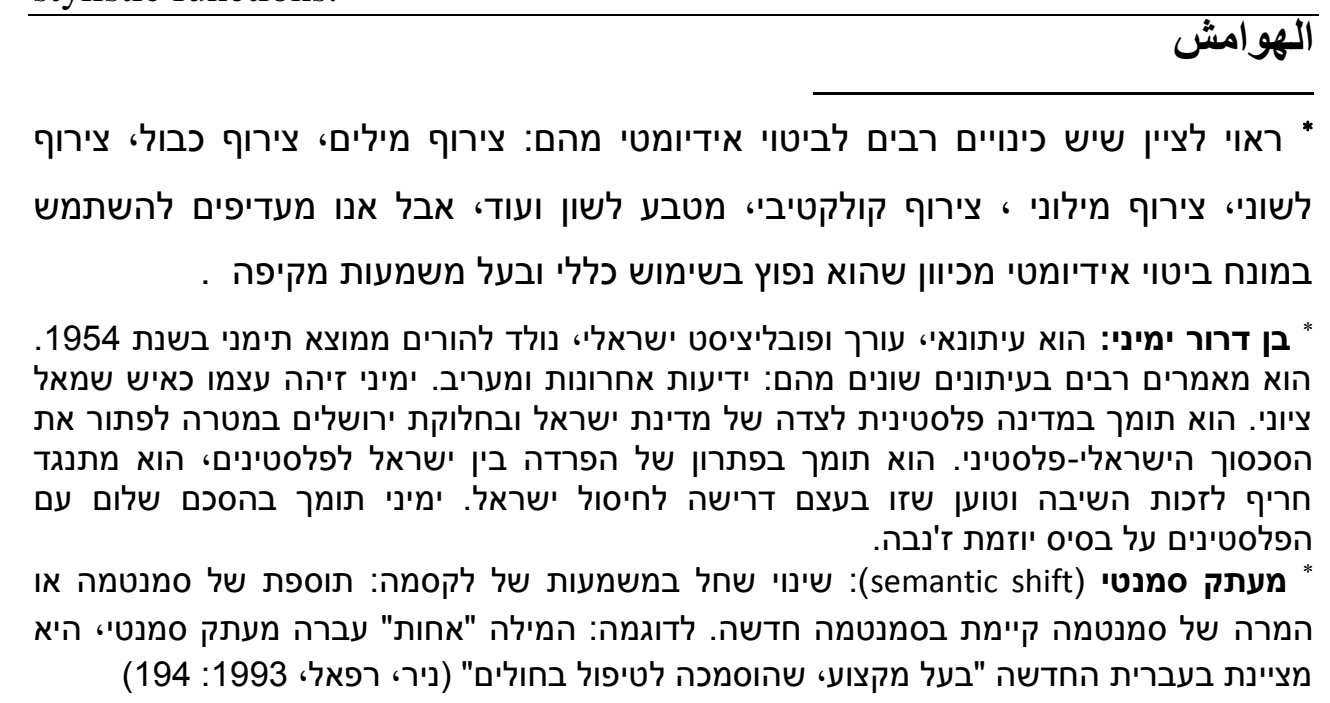

